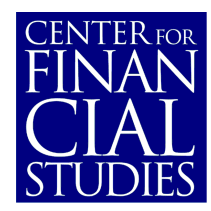

No. $2001 / 13$

Economic Integration and the Exchange Rate Regime: How Damaging are Currency Crises?

Guenter Beck / Axel A. Weber

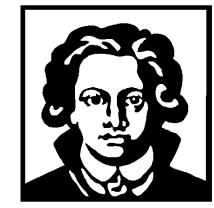




\title{
Economic Integration and the Exchange Rate Regime: How Damaging are Currency Crises?
}

\author{
Guenter Beck (University of Frankfurt) and \\ Axel A. Weber (University of Frankfurt, Center for Financial Studies, and CEPR)*
}

November 2001

\begin{abstract}
:
We use consumer price data for 205 cities/regions in 21 countries to study deviations from the law-of-one-price before, during and after the major currency crises of the 1990s. We combine data from industrialised nations in North America (Unites States, Canada, Mexico), Europe (Germany, Italy, Spain and Portugal) and Asia (Japan, Korea, New Zealand, Australia) with corresponding data from emerging market economies in the South America (Argentine, Bolivia, Brazil, Columbia) and Asia (India, Indonesia, Malaysia, Philippines, Taiwan, Thailand). We confirm previous results that both distance and border explain a significant amount of relative price variation across different locations. We also find that currency attacks had major disintegration effects by significantly increasing these border effects, and by raising within country relative price dispersion in emerging market economies. These effects are found to be quite persistent since relative price volatility across emerging markets today is still significantly larger than a decade ago.
\end{abstract}

Keywords: relative price volatility, spatial data, real exchange rate, law of one price, purchasing power parity, currency crisis, contagion, economic integration

JEL classification: F40, F41

\footnotetext{
* This work is part of a CFS research programme on New Developments in International Economics. It is also part of a CEPR research and training network on Understanding Europe's Role in the Global Econom. Financial support by the Center for Financial Studies and the Commission of the European Communities is gratefully acknowledged. The usual disclaimer applies.
} 


\section{Introduction}

Recent research has aimed at improving our understanding of the magnitude and determinants of deviations from the law-of-one-price (LOOP). One strand of the literature estimates the half-lives of real exchange rates. For most countries and time periods, real exchange rates are found to be highly persistent, with deviations from PPP amongst industrialised nations having half-lives of several years. A second approach focuses on the comparison of movements in goods prices across national borders to price movements between different regions within a country. A seminal paper by Engel and Rogers (1996) finds that both distance and the border are significant in explaining relative price dispersion in 14 U.S. and 9 Canadian locations. They show that (i) relative price variability increases with distance within each country and (ii) U.S.-Canadian relative price variability is significantly larger than within-country variability. They provide a useful measure of how important the border is relative to distance — the "width of the border". Their estimates suggest that crossing the U.S.-Canadian border is equivalent to 1,780 miles of distance, that is, in order to generate the same degree of relative price volatility by distance within a countries, the cities would have to be 1,780 miles apart. By this "width of the border" metric, international failures of the law of one price are large.

The role of borders and geography has increasingly received more attention in economics and a number of recent papers have discovered evidence of such border effects for additional locations. Engel, Hendickson and Rogers (1997) and Parsley and Wei (2000) use data from North America, Asia and Europe to study intra-national, intra-continental and intra-planetary deviations from the law-of-one-price, whilst Engel and Rogers (2000) and Rogers, Hufbauer and Wada (2001) focus exclusively on European locations. A large number of intra-national data are used in Beck and Weber (2001a) who augment the Engel 
and Rogers (1996) data set by regional price level data from 26 Mexican cities, 47 Japanese prefectures, 3 cities in New Zealand and 8 cities in Australia. In two additional papers, Beck and Weber (2001b) and Beck (2001) employ both aggregated CPI data and dis-aggregated data for various categories of consumer goods for 12 German, 20 Austrian, 4 Swiss, 20 Italian, 18 Spanish and 7 Portugese cities to study the integration effects arising from German and European Monetary Union (GEMU and EMU). We find that under EMU the elimination of nominal exchange rate volatility has largely but not completely reduced both the border and distance effects, but distance and border still matter for intra-European relative price volatility in the EMU sample period (January 1999 to July 2001).

The current paper analyses an even larger data set. We use consumer price data for 204 cities/regions in 21 countries to study deviations from the law-of-one-price before, during and after the major currency crises of the 1990s. We combine data from industrialised nations in North America (Unites States, Canada, Mexico), Europe (Germany, Italy, Spain and Portugal) and Asia (Japan, Korea, New Zealand, Australia) with corresponding data from emerging market economies in the South America (Argentina, Bolivia, Brazil, Columbia) and Asia (India, Indonesia, Malaysia, Philippines, Taiwan, Thailand). To our knowledge this is by far the largest spatial price data set employed in the literature to date.

Our estimation equations are similar to the ones used in Engel and Rogers (1996, 2000): the dependent variable is the variance of changes in the log of real exchange rate

\footnotetext{
${ }^{1}$ See Cruchini et al (199?) and O’Connel and Wei (199?) for a broad range of goods prices.

${ }^{2}$ SPATDATC is a CFS databank with spatial consumer price, wage and employment data for sub-national regions/districts/cities from a number of non-European OECD countries (U.S., Canada, Mexico, Japan, New Zealand, Australia), Europe (Austria, Germany, Switzerland, Italy, Spain, Portugal, and Benelux), South America. (Argentina, Bolivia, Brazil, Columbia) and Asia (India, Indonesia, Malaysia, Philippines, Taiwan, Thailand).
} 
across cities, and among the explanatory variables are distance and "border" dummy variables. Since our global data set has city price data from several countries we are able to include in addition to distance simultaneously both a border dummy variable and a measure of nominal exchange rate variability in a regression explaining the variability of (common-currency) prices across cities. This allows us to assess separately the role of nominal exchange rate variability and the effects of a border. Our results indicate that most of the failures of the law of one price are attributable to currency volatility, but other barriers are also important explanatory factors. We find that, even after taking into account nominal exchange rate variability, distance between cities and the border continue to have positive and significant effects on real exchange rate variability.

\section{Data and Econometric Methodology}

As mentioned above, we use consumer price indexes from 205 locations in 21 countries in Europe, Asia and the Americas. The data are monthly, ${ }^{3}$ covering the period January 1991 to June 2001. Appendix Table 1 lists the locations and data sources in the 21 countries for which we have complied aggregate CPI time series. ${ }^{4}$ The nominal exchange rates and national inflation rates used in our study were taken from the IMF's International Financial Statistics database.

Figure 1 displays the national inflation rates and the regional inflation diversity for a selected number of countries in order to highlight the degree of regional heterogeneity in the inflation response to currency crises. From panel 1(c) it is obvious that during the Mexican crisis of 1994 the sharp increase in inflation levels also resulted in a noticeable

\footnotetext{
${ }^{3}$ For the U.S. we used bi-monthly data which for some cities were available for odd month and for other cities for even month only. In the pacific-based sample we moved to quarterly data since CPI data for Australia and New Zealand were available at that frequency only. See the data Appendix for details.

${ }^{4}$ In many countries we had data for more locations available than were used in this study. Our selection was then motivated by two major aspects: to obtain a relatively broad regional coverage whilst at the same time aiming at using large cities with a high population number. We view the latter as a good indicator for market size, and larger markets are typically associated with more competitive price setting.
} 
rise in inflation dispersion across Mexican locations. The same pattern can be identified for Thailand, Indonesia, Korea and the Philippines during the Asian crisis in the second half of 1997. Interestingly, the Asian crisis is also visible in the Indian and Japanese inflation series, which display a similar pattern during this period. We will consider this effect in more detail when we will discuss contagion effects later in the paper.

To our knowledge, spatial CPI data for emerging market economies were not used in previous research, and even the spatial data for some of the industrialised nations included in our paper are employed for the first time in the literature. Using price indices from 205 locations would in principle allow us to construct $20910(=205 * 204 / 2)$ bilateral relative prices. Furthermore, our sample of 21 countries implies that the cross-border city pairs lie across one of $210(=21 * 20 / 2)$ national borders (that are not necessarily adjacent). Note that there are a number of different types of exchange rate arrangements determining the nominal exchange rates of our 210 country pairs. Germany was at the heart of the Exchange Rate Mechanism (ERM) of the European Monetary System (EMS), which was a system of multilateral pegs and developed into a currency union in 1999. Argentina for part of our sample has tied its currency to the U.S. dollar by operating a currency board system. Most Asian countries have operated unilateral pegs vis-à-vis the U.S. dollar before the Asian crisis and were forced to float their exchange rates as a result of the currency attacks. In our empirical estimates we will consider in more detail the characteristics of these exchange rate systems by introducing a number of dummy variables for currency board arrangements, unilateral pegs, free floats, managed floats, currency unions, etc. in order to examine the "hollowing out" (Eichengreen, 1999) hypothesis empirically. A recent analysis of the role of the exchange rate system in explaining economic integration as measured by bilateral trade volumes is found in Rose (2000, 2001), Persson (2001), and the literature cited there. Our paper follows Engel and Rogers (1996) and analyses the impact of the exchange rate system on economic integration as measured by relative price volatility across locations within and between countries.

We are aware that there are other important determinant of economic integration between countries in addition to distance, national borders and the exchange rate system. One key factor is the existence of formal free-trade arrangements. Some of the countries under study were members of free-trade areas such as the European Union (EU), the North 
American Free Trade Arrangement (NAFTA), the South American MERCOSUR or the ASEAN agreement. Membership in the World Trade Organisation (WTO) or the General Agreement on Tariffs and Trade (GATT) are other possible indicators of a high degree of openness. Membership in such arrangements should have a negative effect on relative price volatility since the literature has shown that a significant link exists between trade linkages, economic integration and relative price volatility. Finally, other potentially important determinants of economic integration are cultural factors, such as a common language or a common history. ${ }^{5}$ In our empirical work we will allow for these influences in addition to controlling for distance and the existence of a boarder when estimating the impact of currency crises on economic integration as measured by relative price volatility.

\subsection{Data Properties: Summary Statistics on Relative Volatility and Distance}

We denote the log of the CPI in location $j$ relative to that in location $k$ as $P(j, k)$. All prices are denominated in a common currency, the U.S. dollar. ${ }^{6} \mathrm{We}$ are interested in explaining the volatility of changes in $P(j, k)$ across locations. We consider two-month changes in relative prices, $\Delta P(j, k)$ and we measure volatility as the sample variance, $V(\Delta P(j, k))$, which is referred to as volatility measure 1 hereafter.

As mentioned above, we construct our measure of volatility for each of the city pairs. Our regression analysis is then based on the cross-section of volatility measures. Tables 1a, $1 \mathrm{~b}$ and $1 \mathrm{c}$ presents some summary statistics. The various rows report the average relative real exchange volatility and its cross-sectional dispersion between all 21 pairs of locations that are both within the same country, [i.e. within the U.S. (us-us), within Canada (ca-ca), within Mexico (mex-mex)] as well as all 189 combinations of cross-border city pairs (us-ca, us-mex, ca-mex, etc.). A key feature of our analysis is that we draw a

\footnotetext{
${ }^{5}$ The 21 countries used in this study also differ along geographic, linguistic, and cultural lines. In our sample Portugal and Brazil share a common language. The same is true for Spain, Argentina, Mexico, Columbia, and Bolivia on the one side, and the United States, Canada, Australia, New Zealand and India. Many countries in our sample share a common border with at least one adjacent country, some have joint borders with two or more neighbouring countries and third group of countries have no common borders with any other countries in the sample. Note that our study takes explicit account of such geographic factors (common borders, physical distance) and cultural linkages (common language, which may contribute to explaining economic integration between countries.
} 
distinction between cases where both locations are within the same country (labelled intranational), and cases with one city in one country and the other city in a foreign country (labelled international). We also distinguish between the case where both locations are within the same continent (intra-continental) in North America, South America, Europe, Asia and the Pacific and those cases where they are on different continents (intercontinental). This distinction was introduced by Engel, Rogers and Hendickson (1997). Other useful ways to characterise the global linkages between the various locations is to distinguish between industrialised and emerging market economies or to follow Mussa and Masson (199?), who in their study of the Asian crisis have analysed "monsoonal effects", that is the spill-over between Asian and Southern American emerging markets, whilst they referred to the spill-over within Asia as "contagion effects".

Table 1a summarises the data by continental blocs. For all periods we find that average intra-national relative price volatility is consistently lower than average crossborder volatility both within and between continental blocs. Intra-national volatility is also fairly constant and does not display a downward or upward trend; rather, it fluctuates around its period average of 0.011 (s.e. 0.006) during the four sub-periods. Table 1a also reveals a relatively low initial intra-continental volatility in North America (0.0204, s.e. $=0.0025)$ and a moderate inter-continental volatility between North America and Asia (0.0318, s.e. $=0.0175)$. Relative price volatility between North America and South American or the Pacific region are somewhat higher and of similar size as the intra-Asian volatility $(0.0389$, s.e. $=0.0195)$. Finally, note that the highest intra-continental volatility is initially found for city pairs in South America $(0.046$, s.e. $=0.011)$. The three major currency crisis drastically disturb this volatility pattern and are clearly identifiable both in the volatility both within these continents and between these continents and the rest of the world.

Table $1 \mathrm{~b}$ provides more detailed summary statistics for the individual country-pairs within and between the above continents. Here we focus on the pre-crisis period (1991.I94.XI). Table $1 \mathrm{~b}$ confirms that the average volatility of cross-border pairs of 2-month relative price changes is noticeably larger than the average variance of within-country

\footnotetext{
${ }^{6}$ We also employ a Europe-based (DM-based) and a Pacific-based (Australian dollar-based) sample to check the sensitivity of the results with respect to choice of the numeraire currency.
} 
pairs. Consider the case of North America. Within Canada, the United States and Mexico city pairs exhibit a low average volatility between 0.0041 and 0.0069 , whilst the crossborder averages between Canada, Mexico and the U.S. range between 0.018 and 0.023, which is roughly three times as large. Within-country volatility in many Asian and Pacific countries (Japan, Korea, Malaysia, and Thailand) is of compatible size to that in North America, but in Southern America (Argentina, Bolivia, Brazil, Columbia) and in some parts of Asia (India, Indonesia) it reaches almost the size of the U.S.-Canadian crossborder relative price volatility. The largest volatility measures are found for the intercontinental cross-border city pairs between emerging market economies in South America and Asia, and in particular in relation to India. The largest volatility measure reported in Table $1 \mathrm{~b}$ is 0.069 for Brazil versus India, which is roughly 14 times as large as the corresponding U.S.-Canada number.

Figure 2 provides an even closer look at our data for the pre-crisis period (1991-94) by displaying the relative price volatility between our 20910 city pairs in 12 separate graphs for the various intra-national, intra-continental and intercontinental combinations. Comparing panels 2(a) and 2(b) reveals that some intra-national city-pairs have a relative price volatility that is as high that of the North-American intra-continental city-pairs, but the latter tend to lie further apart. It is also obvious from panels 2(c) and 2(d) that at roughly the same distance as in North America the South American and Asian intracontinental city-pairs display a much larger relative price volatility. Except for the AsianPacific panel the intercontinental city-pairs lie even further apart and also have higher volatility, but there exists a quite diverse patterns. To summarise, at a first glance the data appear to support the hypothesis of Engel and Rogers (1996) that a high relative price volatility between very distant city pairs is a good indicator of a low degree of economic integration.

\subsection{Regression Analysis}

Engel and Rogers $(1996,2000)$ examine the hypothesis that the volatility of the prices of similar goods sold in different locations is related to the distance between the locations and other explanatory variables, including a dummy variable for whether the 
cities are in different countries. Relative price volatility is the standard deviation of the difference in the log of relative prices between time $t$ and $t-2, V(\Delta P(j, k)$. This will be referred to as measure 1 in our analysis below, and we will perform robustness checks in which we employ the spread between the 10th and 90th percentiles (measure 2) and a filtered measure (measure 2) and as alternative measures of volatility. Our results were essentially unaffected by the specific choice of the volatility measure.

In the analysis below we present the results of our estimates of regression equations of the form:

$$
\begin{aligned}
& V(\Delta P(j, k))=\Sigma \alpha(c) D(c)+\beta \log (d(j, k))+\delta B(j, k)+\gamma W(\Delta s(j, k))+\varepsilon X(j, k)+u(j, k) \\
& V(\Delta P(j, k))=\Sigma \alpha(c) D(c)+\beta_{1} d(j, k)+\beta_{2} d(j, k)^{2}+\delta B(j, k)+\gamma V(\Delta s(j, k))+\varepsilon X(j, k)+u(j, k)
\end{aligned}
$$

where $D(c)$ is a dummy variable for each city in our sample, $d(j, k)$ is the log distance between cities $j$ and $k, B(j, k)$ is a dummy variable for each national border that separates cities $j$ and $k, V(\Delta s(j, k))$ is a measure of nominal exchange rate volatility between cities $j$ and $k$ located in different countries and $X(j, k)$ are other explanatory variables, such as a dummy variable for fixed, floating or intermediate exchange rate system or a dummy for the existence of formal free trade arrangements (NAFTA, EU, ASEAN, MERCADOR).

Note that all regressions are cross-sectional, and we would have been able to use a maximum of 20910 observations. To keep the computational task manageable, we will focus much of our analysis on a U.S.-based cross-country sample with only 11026 citypairs and check the sensitivity of our results by also employing a Europe-based sample (13861 city-pairs) and a Pacific-based sample (10878 city-pairs). Note that the inclusion of separate dummies for each individual location allows the variance of price changes to vary from city to city. That is, for city pair $(j, k)$ the dummy variables for city $j$ and city $k$ take on values of 1 . This takes into account the possibility of idiosyncratic measurement error or seasonalities in some cities that may make their prices more volatile than others. Second, as Table 1 indicates, there seems to be somewhat higher average price volatility between cities in emerging markets economies as opposed to cities in industrialised countries. This may be because emerging markets are more heterogeneous countries. Either labour markets or goods markets may be less integrated, so there can be greater discrepancies in 
prices between locations. Alternatively, there may be differences in methodologies for recording prices that lead to greater discrepancies in prices between locations in one country compared to the other.

Following Engel and Rogers (1996) we assume that relative price volatility will be larger the greater the distance $d(j, k)$ between locations, due to "transportation costs." The key argument here is that in the presence of transportation costs prices in one location are not necessarily equalised with prices in another location, and that the relative price could fluctuate in a range which is likely to be a function of the transportation cost and hence the distance between the locations. Equation (1) postulates that goods markets between more distant locations are less integrated and therefore have greater price dispersion. We postulate either a log-linear $(\beta>0)$ or a concave $\left(\beta_{1}>0\right.$ and $\left.\beta_{2}<0\right)$ relationship between distance and relative price volatility, and we interpret "transportation costs" liberally to include any factors that make it more costly to sell goods in one location compared to another. ${ }^{7}$

We are particularly interested in whether there is a border effect. We expect the variability of prices between cities that lie across a border to be higher than those between cities within a country, even after accounting for the effect of distance and nominal exchange rate volatility. The recent literature on pricing-to-market has examined markets that are segmented by borders, and it has been emphasised that the mark-up is likely to be different across locations and may vary with exchange rate changes. There might also be direct costs to crossing borders because of tariffs and other trade restrictions. In addition, there may be more homogeneity in relative productivity shocks for city pairs within the same country than for cross-border city pairs, so that, from equation (1), cross-border pairs have more price volatility. ${ }^{8}$ To capture this effect, we include a border dummy variable, $B(j, k)$, that takes on a value of unity if cities $j$ and $k$ are in different countries. This border dummy is likely to capture both formal and informal international barriers to trade. We typically find the border-effect to be positive and significant.

\footnotetext{
${ }^{7}$ For example, there may be trade barriers or marketing and distribution costs.

${ }^{8}$ Engel and Rogers (2000) suggest sticky prices of consumer goods are another reason why the border may matter: goods sold in the Japan might have sticky prices in Yen terms and goods sold in the United States might have sticky prices in U.S. dollar terms, whilst the nominal exchange rate is highly variable. In this case, the cross-border prices would fluctuate along with the exchange rate, but the within-country prices would be fairly stable.
} 


\section{Estimation Results}

Table 2 summarises our estimation results for regression equation (1) and volatility measures 1 during the overall sample period (1991:I-2001:VI) and for four different subperiods, which are the pre-Mexican-crisis period (1991.I-1994:XI), the pre-Asian-crisis period (1994:XII-1997:VI), the pre-Brazilian-crisis period (1997:VII-1998:XI) and the post-Brazilian-crisis period (1999:I-2001.VI). The five columns report the estimated coefficients and standard errors from regressing the variance of the 2-month change in the $\log$ relative price on log distance, 105 borders, and 149 individual location dummies (one for each of our cities, not reported for convenience). Almost all coefficients in all subsamples have the anticipated sign and are significant at least at the 5 percent level.

Let us consider the pre-crisis sample first. The coefficient on the border dummies range between 2.4 for the U.S.-Indonesian border to 58.4 for the Columbian-Malasian border, which is almost 25 times as large. The individual dummies for each border, of which due to problems with data availability for Taiwan in the early sample there are only $91(=14 * 13 / 2)$, all have the expected sign and are significant. Note that the smallest border estimates are found in all bilateral combinations between the United States, Indonesia, Thailand, Malaysia and Korea. Our simple border metric indicates that these countries, which a few years later were at the core of the Asian currency crisis, had a considerably higher degree of economic integration with the United States than Canada, for which we estimate a border coefficient of 11.3 (s.e. 0.29). ${ }^{9}$ We attribute this to the unilateral U.S. dollar pegs operated by most of these countries in the early 1990s, and we will later attempt to discriminate between the border effect and the impact the exchange rate system on relative price volatility. At first glance, all the positive and significant estimates of the border effects confirm the results documented by Engel and Rogers $(1996,2000)$ that crossing an international border adds considerable volatility to relative city prices, even after accounting for the effects of distance and city-specific characteristics.

What impact did the various exchange rate crises have on these initial conditions? The remaining rows of Table 2 report our estimates for the Mexican, Asian and Brazilian

\footnotetext{
${ }^{9}$ Our results which disregard European and Pacific locations identify 18 bilateral country pairs which were more integrated with each other than the U.S. and Canada were during 1991-94.
} 
currency crises. To visualise these results, panel (a) of Figure 4 provides a scatter-plot of our estimates for the pre-Mexican and post-Mexican crisis. For many countries our border metric indicates progress in economic integration since most of the estimates are below the $45^{\circ}$ line. The major exception are the bilateral combinations with respect to Mexico and Japan. Whilst for Mexico this disintegration is clearly due to the currency crisis, the Japanese volatility pattern cannot be viewed as an outcome of this crisis. Rather, a lack of progress on liberalising trade and a weak and volatile yen are at the core of these disintegration effects. As in the pre-crisis sample, we find that both distance and most bilateral border effects are significant during the Mexican-crisis sample.

A vastly different picture is revealed by panel (b) of Figure 4, which compares our estimates for the Mexican-crisis and the Asian crisis periods. Whilst the Mexican crisis was clearly identified as a local crisis primarily affecting the country under attack by currency speculators, the Asian crisis was a truly global phenomenon. According to our metric it brought about major disintegration effects that were no longer contained regionally. The most drastic effects are identified for Indonesia, which experiences a major surge in inflation and a vast decline in its U.S. dollar exchange rate. Another country hit hard by the Asian crisis is Korea, followed by the Philippines and Thailand. In fact, the only country in our sample that experienced some integration progress during the sample was Mexico, which in the later part of the 1990s stabilised and in part recovered from the 1994 crisis.

The latter finding raises the issue how persistent the disintegration effects of the currency crises were. Panel (c) of Figure 4 addresses this question. When we compare the early sub-sample (1991.I-1994.XI) and the most recent data (1999.I-2001.VI) we find that our measure of economic integration today still has not fully recovered from the successive crises in Mexico, Asian and Brazil, but at the same time considerable progress has been made to recover from the negative global impact of these crises.

So just how damaging are currency crises? Whilst the cross-country estimates of border effects are very sensitive with respect to nominal exchange rate movements, a robust indicator of the disintegration effects of currency attacks is provided by the withincountry effects of the crises on relative price volatility between city pairs. Figure 5 displays these volatility measures for the above sub-periods. We find that the within-country 
disintegration effects closely resemble the cross-country effects discussed above. For example, during the Asian crisis the within-country disintegration effects are particularly pronounced for Indonesia and India, and the latter finding clearly witnesses contagion within Asia. We interpret these findings as follows: whilst a large part of the cross-country evidence might be due to a nominal border effect working through the exchange rate, the former effect is a truly real effect that arises from an impact of the crisis on price dispersion within countries.

How sensitive are these results with respect to changes in functional forms or the particular volatility measure employed? To address this issue, we conducted numerous sensitivity checks, but due to space constraints we will only briefly discuss two such modifications. For the overall period (1991.I-2001.VI) our Appendix Table 2a also displays the results when the distance function is quadratic, rather than logarithmic. This is reported as specification 2, which is interesting because it allows a test for our assumption of a concave distance relationship. We find that distance has a significantly positive effect on price variability, whilst the square of distance has a significantly negative effect, as is postulated by a concave distance relationship. Again border dummy is positive and significant. Like Engel and Rogers $(1996,2000)$ we also perform further robustness checks in which we employ alternative measures of relative price volatility based on the spread between the 10th and 90th percentiles (measure 2). The results are reported in Appendix Table $2 \mathrm{~b}$, which shows that these modifications do also not affect the key features of our results. In both cases we find that the coefficients on distance and the border dummies are highly significant and of the hypothesised sign.

What explains the relative sizes of these border effects? Nominal exchange rate variability is a prime candidate. Replacing the individual border dummies by one aggregate border dummy allows us to include in one regression specification both the border dummy and the variability of two-month nominal exchange rate changes, which of course is zero for all intra-national pairs. The results are reported in Table 3. For our overall sample the coefficient on nominal exchange rate variability is 0.354 (s.e. $=0.0256$ ). Including nominal exchange rate variability substantially weakens the effect of the border dummy, whose point estimate falls from 65.6 to 29.1 . This suggests that a very large part of the border effect is from variable nominal exchange rates under sticky prices. However, even with 
$V(\Delta s(j, k))$ in the regression, the border dummy remains positive and significant with a $t$ statistic exceeding 17. Thus, we conclude that the significance of border effects is not exclusively the result of nominal exchange rate volatility, and that other factors appear to also matter.

To identify such factors we have augmented our baseline regression by including geographic (adjacency, landlocked) and cultural factors (common language or history) as well as indicators of the exchange rate regime (fixed, free float, managed float, peg, currency board) or trade arrangement (EU, NAFTA, ASEAN, MERCADOR, GATT). The results are also reported in Table 3 (incomplete, results to be added). Whilst we find no significant effect of NAFTA, membership in the ASEAN club appears to have a significant negative effect on relative price volatility of its member countries as compared to the rest of the cross-section of countries. The trade bloc variable furthermore decreases the importance of the border effect whilst leaving the impact of nominal exchange rate volatility unaltered. [FURTHER RESULTS TO BE ADDED HERE ...]

\section{Summary and Policy Conclusions}

The key message of our paper is that the major currency crises of the 1990s have had a sizeable disintegration effect by considerably distorting the law-of-one-price between the major industrialised and emerging market economies. These effects have been quite persistent and nowadays relative price volatility between and within emerging markets economies is still considerably larger than a decade ago. This adverse effect on economic integration arising from a significantly increase in cross-border relative price volatility is not just due to nominal exchange rate volatility. In trying to explain the relative sizes of the border effects we show that whilst controlling for nominal exchange rate variability somewhat weakens the effect of the border, the latter remains highly significant in all regressions. Our attempts to also control for geographic and cultural factors, the characteristics of the exchange rate regime or membership in free trade arrangements in all 
cases influences the estimated integration measures (the width of the border) somewhat, but their significance is unaltered by this sensitivity checks. For example, the trade bloc variable decreases the importance of the border effect whilst leaving the impact of nominal exchange rate volatility unaltered. [FURTHER RESULTS TO BE ADDED HERE]

What are the policy implications of these findings? The literature on pricing to market has emphasised that when markets are segmented, price discrimination can occur. The finding that distance is important in explaining global price differences between locations in the Americas, Europe, Asia and the Pacific lends support to this literature. The major currency crises are found to have greatly increased the importance of intracontinental and intercontinental borders, and to even have had adverse effects on withincountry relative price volatility. Our width-of-the-border metric suggests that currency crises have produced a "continental drift" phenomenon and thereby added to economic distance between global markets. Our estimates confirm that global product markets are still segmented, and that segmentation has increased under the crises of the 1990s. A policy aimed at securing a stable global financial architecture and preventing currency crises are a key ingredient in fostering trade and the establishing globally integrated product markets.

\section{Data Appendix}

Our data are described in detail in Appendix Table A1. All of the price data (for all countries) are seasonally unadjusted. We use comparable price data for the aggregate CPI. Consumer price data are closer to being monthly average data than point-in-time data. In order to compare prices internationally we use a monthly average exchange rates from the IMF (International Financial Statistics). As the basis for our regressions we calculated the inter-city relative prices. We also use data on the distance between cities. We use a 
measures of distance obtained from the "How Far IS?" software. Our distance measure is the great-circle distance. 


\section{References}

Beck, G. and A.A. Weber, 2001a, How wide is the Pacific?, mimeo.

Beck, G. and A.A. Weber, 2001b, „How wide are European borders? - On the Integration Effects of Monetary Unions, " mimeo.

Cecchetti, S.G., C.M. Nelson and R. Sonora, 1999, „Price Level Convergence Among United States Cities: Lessons for the European Central Bank, " mimeo.

Dornbusch, R., 1987, Exchange Rates and Prices, American Economic Review 77, 93-106.

Dumas, B., 1992, Dynamic Equilibrium and the Real Exchange Rate in a Spatially Separated World, Review of Financial Studies, 153-180.

Edison, H.J., J.E. Gagnon, and W.R. Melick, 1997. Understanding the empirical literature on purchasing power parity: the post-Bretton Woods era. Journal of International Money and Finance 16, 1-17.

Eichengreen, Barry (1999) Toward a New International Financial Architecture, Washington, The Institute for International Economics.

Engel, C., 1993. Real exchange rates and relative prices: an empirical investigation. Journal of Monetary Economics 32, 35-50.

Engel, C., 1999. Accounting for U.S. real exchange rate changes. Journal of Political Economy, forthcoming.

Engel, C. and J.H. Rogers, 1996, „How Wide Is the Border?““ American Economic Review $86,1112-1125$.

Engel, C., M.K. Hendrickson, and J.H. Rogers, 1997. Intra-national, intra-continental and intra-planetary PPP. Journal of the Japanese and International Economies 11, 480501.

Engel, C. and J.H. Rogers, 1998, Regional patterns in the law of one price: The roles of geography versus currencies, in, Jeffrey A. Frankel, ed., The regionalization of the world economy (Chicago: University of Chicago Press.)

Engel, C. and J.H. Rogers, 2000, Deviations from purchasing power parity: causes and welfare consequences, Journal of International Economics, forthcoming.

Frankel, J.A. and A. Rose, 1996. A panel project on purchasing power parity: mean reversion within countries and between countries. Journal of International Economics 40, 209-224.

Frankel, J.; E. Stein and W. Shang-Jin, 1995, "Trading Blocs and the Americas: The Natural, the Unnatural and the Super-natural.' Journal of Development Economics 67, 61-96.

Helliwell, J., 1996, Do national borders matter for Quebec's trade?, Canadian Journal of Economics 29, 507-522.

Helliwell, J., 1998, How much do national borders matter?, manuscript.

Isard, P., 1977, How Far Can We Push the Law of One Price?, American Economic Review 67, 942-48.

Knetter, M.N., 1989, Price Discrimination by U.S. and German Exporters, American Economic Review 79, 198-210.

Krugman, Paul, 1987, Pricing to market when the exchange rate changes, in Sven W. Arndt and J.David Richardson, eds., Real-financial linkages among open economies (Cambridge, MA.: MIT Press), 49-70.

Krugman, P., 1991, Geography and trade (Cambridge, MA.: MIT Press). 
McCallum, J., 1995, National borders matter: regional trade patterns in North America, American Economic Review 85, 615-623.

Mussa, M., 1986, Nominal Exchange Rate Regimes and the Behavior of Real Exchange Rates: Evidence and Implications, Carnegie-Rochester Conference Series on Public Policy 25, 117-214.

Newey, W.K. and K.D. West, 1987. A simple positive semi-definite, heteroskdeasticity and autocorrleation consistent covariance matrix. Econometrica 55, 703-708.

Obstfeld, M. and A. Taylor, 1997. Nonlinear aspects of goods-market arbitrage and adjustment: Heckscher's commodity points revisited. Journal of the Japanese and International Economies 11, 441-478.

O'Connell, P., 1998. The overvaluation of purchasing power parity. Journal of International Economics 44, 1-19.

O'Connell, P.J. and S.-J. Wei, 1997, The bigger they are, the harder they fall: How price differences across cities are arbitraged, National Bureau of Economic Research, working paper no. 6089.

Parsley, D. and S.-J. Wei, 1996, Convergence to the law of one price without trade barriers or currency fluctuations, Quarterly Journal of Economics 111, 1211-1236.

Parsley, D. and S.-J. Wei, 2000, Border, border, wide and far, how we wonder what you are, Journal of International Economics, forthcoming.

Persson, T., 2001, Currency Unions and Trade: How Large is the Treatment Effect?, Economic Policy 33, 435-448.

Rogoff, K., 1996, The purchasing power parity puzzle, Journal of Economic Literature 34, 647-668.

Rogers, J.H., 1999, Monetary shocks and real exchange rates, Journal of International Economics 49, 269-288.

Rogers, J.H. and M. Jenkins, 1995, Haircuts or hysteresis? Sources of movements in real exchange rates, Journal of International Economics 38, 339-360.

Rogers, J.H, G.C. Hufbauer and E. Wada, 2001, Price Level Convergence and Inflation in Europe, Institute for International Economics Working Paper No. 01-1.

Rose, A., 2000, One Money, One Market: The Effects of Common Currencies on Trade, Economic Policy 30, 7-45.

Rose, A., 2001, Currency Unions and Trade: The Effect is Large, Economic Policy 33, 449-461.

Wei, S.-J. and D.C. Parsley, 1995. Purchasing power disparity during the floating rate period: exchange rate volatility, trade barriers and other culprits. National Bureau of Economic Research, working paper No. 5032.

Wei, S.-J., 1996, Intra-national versus inter-national trade, National Bureau of Economic Research, working paper no. 5531.

Wolf, H., 1997, Patterns of intra- and inter-state trade, National Bureau of Economic Research, working paper no. 5939.

White, H., 1980, A Heteroskedasticity-Consistent Covariance Matrix Estimator and a Direct Test for Heteroskedasticity, Econometrica 48, 817-38. 
Table 1 a:

Descriptive Statistics, Relative Price Volatility, US Sample, 1991.01 - 1994.11, Measure 1

Relative Locations, Indicated by Continent Names, Grouped by Continents

\begin{tabular}{|c|c|c|c|c|c|c|c|c|c|c|}
\hline \multirow[t]{2}{*}{ Continent Pairs } & Mean & Stdv. & Mean & Stdv. & Mean & Stdv. & Mean & Stdv. & Mean & Stdv. \\
\hline & \multicolumn{2}{|c|}{$1991.01-2001.06$} & \multicolumn{2}{|c|}{ 1991.01 - 1994.11} & \multicolumn{2}{|c|}{$1994.12-1997.06$} & \multicolumn{2}{|c|}{$1997.07-1998.12$} & \multicolumn{2}{|c|}{ 1999.01-2001.06 } \\
\hline Intranational & 0.01093 & 0.00589 & 0.01060 & 0.00628 & 0.00976 & 0.00488 & 0.01211 & 0.01039 & 0.00923 & 0.00711 \\
\hline Within North America & 0.05065 & 0.01907 & 0.02040 & 0.00246 & 0.06947 & 0.03102 & 0.03824 & 0.01238 & 0.02645 & 0.00536 \\
\hline North vs. South America & 0.05843 & 0.02337 & 0.03772 & 0.01190 & 0.05193 & 0.03412 & 0.03774 & 0.01882 & 0.05087 & 0.01583 \\
\hline North America vs Asia & 0.08061 & 0.04024 & 0.03182 & 0.01757 & 0.04699 & 0.03260 & 0.16228 & 0.12840 & 0.04317 & 0.02572 \\
\hline North America vs. Pacific & 0.06471 & 0.01528 & 0.03931 & 0.00354 & 0.08196 & 0.02304 & 0.07961 & 0.01151 & 0.04978 & 0.00423 \\
\hline Within South America & 0.05036 & 0.01606 & 0.04663 & 0.01110 & 0.02775 & 0.00856 & 0.03833 & 0.02010 & 0.06905 & 0.01346 \\
\hline South America vs. Asia & 0.08390 & 0.03844 & 0.04382 & 0.01604 & 0.02678 & 0.00906 & 0.16313 & 0.12778 & 0.06374 & 0.02327 \\
\hline South America vs. Pacific & 0.06578 & 0.01145 & 0.04763 & 0.00763 & 0.05997 & 0.00651 & 0.08581 & 0.01693 & 0.07187 & 0.01310 \\
\hline Within Asia & 0.09065 & 0.04236 & 0.03889 & 0.01952 & 0.02654 & 0.00864 & 0.20256 & 0.11202 & 0.05383 & 0.03040 \\
\hline Asia vs. Pacific & 0.07954 & 0.03233 & 0.04512 & 0.01518 & 0.05851 & 0.00915 & 0.15218 & 0.11069 & 0.06075 & 0.02598 \\
\hline
\end{tabular}


Table 1 b:

Intra-Continental Descriptive Statistics, Relative Price Volatility, US Sample, 1991.01 - 1994.11, Measure 1

Relative Locations, Indicated by Country Names, Grouped by Continents

\begin{tabular}{|c|c|c|c|c|c|c|c|c|c|c|c|}
\hline \multicolumn{3}{|c|}{ North Am. - North Am. } & \multicolumn{3}{|c|}{ South Am. - South Am. } & \multicolumn{3}{|c|}{ Asia-Asia } & \multicolumn{3}{|c|}{ Pacific - Pacific } \\
\hline Country & Mean & Stdv. & Country & Mean & Stdv. & Country & Mean & Stdv. & Country & Mean & Stdv. \\
\hline us-us & 0.00688 & 0.00153 & ar-ar & 0.012 & 0.00355 & indi-indi & 0.01653 & 0.00408 & ja-ja & 0.00501 & 0.0013 \\
\hline us-ca & 0.01757 & 0.0011 & ar-bo & 0.01784 & 0.00253 & indi-indo & 0.06107 & 0.00323 & & & \\
\hline us-me & 0.01962 & 0.00163 & ar-br & 0.05361 & 0.0039 & indi-ko & 0.05918 & 0.003 & & & \\
\hline ca-ca & 0.00531 & 0.00098 & ar-co & 0.0465 & 0.0023 & indi-ma & 0.01684 & 0.00403 & & & \\
\hline ca-me & 0.02279 & 0.00097 & bo-bo & 0.00807 & 0.00216 & indi-ph & 0.05923 & 0.00331 & & & \\
\hline me-me & 0.00408 & 0.00069 & bo-br & 0.0314 & 0.00376 & indi-ta & & & & & \\
\hline & & & bo-co & 0.04531 & 0.0027 & indi-th & 0.05609 & 0.00328 & & & \\
\hline & & & br-br & 0.02361 & 0.00581 & indo-indo & 0.01231 & 0.00253 & & & \\
\hline & & & br-co & 0.05458 & 0.00414 & indo-ko & 0.01461 & 0.00209 & & & \\
\hline & & & co-co & 0.01081 & 0.0034 & indo-ma & 0.01992 & 0.00493 & & & \\
\hline & & & & & & indo-ph & 0.03075 & 0.0024 & & & \\
\hline & & & & & & indo-ta & & & & & \\
\hline & & & & & & indo-th & 0.01717 & 0.00241 & & & \\
\hline & & & & & & ko-ko & 0.00609 & 0.00133 & & & \\
\hline & & & & & & ko-ma & 0.01734 & 0.00197 & & & \\
\hline & & & & & & ko-ph & 0.02848 & 0.00172 & & & \\
\hline & & & & & & ko-tai & . & & & & \\
\hline & & & & & & ko-th & 0.01505 & 0.00189 & & & \\
\hline & & & & & & ma-ma & 0.00662 & 0.00294 & & & \\
\hline & & & & & & ma-ph & 0.02746 & 0.00268 & & & \\
\hline & & & & & & ma-ta & . & . & & & \\
\hline & & & & & & ma-th & 0.01334 & 0.00209 & & & \\
\hline & & & & & & ph-ph & 0.01227 & 0.0021 & & & \\
\hline & & & & & & ph-ta & & & & & \\
\hline & & & & & & ph-th & 0.03019 & 0.00179 & & & \\
\hline & & & & & & ta-ta & . & . & & & \\
\hline & & & & & & $\begin{array}{l}\text { ta-th } \\
\text { th-th }\end{array}$ & 0.0062 & 0.00122 & & & \\
\hline
\end{tabular}


Table 1 c:

Cross-Continental Descriptive Statistics, Relative Price Volatility, US Sample, 1991.01 - 1994.11, Measure 1

Relative Locations, Indicated by Country Names, Grouped by Continents

\begin{tabular}{|c|c|c|c|c|c|c|c|c|c|c|c|}
\hline \multicolumn{3}{|c|}{ North Am. - South Am. } & \multicolumn{3}{|c|}{ North Am. - Asia } & \multicolumn{3}{|c|}{ South Am. - Asia } & \multicolumn{3}{|c|}{ South Am. - Pacific } \\
\hline Country & Mean & Stdv. & Country & Mean & Stdv. & Country & Mean & Stdv. & Country & Mean & Stdv. \\
\hline us-ar & 0.02384 & 0.00343 & us-indi & 0.05644 & 0.00364 & ar-indi & 0.06503 & 0.00349 & ar-ja & 0.04363 & 0.00182 \\
\hline us-bo & 0.0132 & 0.00181 & us-indo & 0.01324 & 0.00234 & ar-indo & 0.02607 & 0.00234 & bo-ja & 0.03731 & 0.00075 \\
\hline us-br & 0.04032 & 0.00859 & us-ko & 0.01116 & 0.0017 & ar-ko & 0.02613 & 0.0016 & br-ja & 0.05804 & 0.00484 \\
\hline us-co & 0.037 & 0.00237 & us-ma & 0.01578 & 0.0041 & ar-ma & 0.01553 & 0.0035 & co-ja & 0.04507 & 0.00206 \\
\hline ca-ar & 0.02748 & 0.00204 & us-ph & 0.02919 & 0.00238 & ar-ph & 0.03558 & 0.00255 & & & \\
\hline ca-bo & 0.01935 & 0.00191 & us-ta & & & ar-ta & & . & & & \\
\hline ca-br & 0.04451 & 0.00343 & us-th & 0.01231 & 0.00238 & ar-th & 0.02653 & 0.00181 & & & \\
\hline ca-co & 0.04503 & 0.00215 & ca-indi & 0.06244 & 0.0028 & bo-indi & 0.04963 & 0.00306 & \multicolumn{3}{|c|}{ North Am. - Pacific } \\
\hline me-ar & 0.02663 & 0.00174 & ca-indo & 0.01834 & 0.00214 & bo-indo & 0.01584 & 0.0026 & us-ja & 0.03429 & 0.00109 \\
\hline me-bo & 0.02215 & 0.00209 & ca-ko & 0.02001 & 0.00128 & bo-ko & 0.01681 & 0.00197 & $c a-j a$ & 0.03874 & 0.00067 \\
\hline me-br & 0.04959 & 0.0032 & ca-ma & 0.02668 & 0.00298 & bo-ma & 0.02337 & 0.00627 & me-ja & 0.0427 & 0.00072 \\
\hline \multirow[t]{16}{*}{ me-co } & 0.05135 & 0.00205 & ca-ph & 0.03 & 0.00207 & bo-ph & 0.03348 & 0.00206 & & & \\
\hline & & & ca-ta & & & bo-ta & & & & & \\
\hline & & & ca-th & 0.01904 & 0.00117 & bo-th & 0.01565 & 0.0016 & & & \\
\hline & & & me-indi & 0.05987 & 0.00279 & br-indi & 0.06914 & 0.00407 & & & \\
\hline & & & me-indo & 0.02219 & 0.00195 & br-indo & 0.0449 & 0.00426 & & ia - Pacific & \\
\hline & & & me-ko & 0.02271 & 0.00121 & br-ko & 0.04249 & 0.00346 & indi-ja & 0.06805 & 0.00321 \\
\hline & & & me-ma & 0.02917 & 0.00278 & br-ma & 0.05831 & 0.00622 & indo-ja & 0.03492 & 0.00242 \\
\hline & & & me-ph & 0.03241 & 0.00175 & br-ph & 0.04682 & 0.00342 & ja-ko & 0.03539 & 0.00052 \\
\hline & & & me-ta & & & br-ta & & 6. & ja-ma & 0.02708 & 0.00116 \\
\hline & & & me-th & 0.02415 & 0.00141 & br-th & 0.04385 & 0.00439 & ja-ph & 0.04979 & 0.00134 \\
\hline & & & & & & co-indi & 0.06485 & 0.00353 & ja-ta & . & \\
\hline & & & & & & co-indo & 0.03781 & 0.00246 & ja-th & 0.02785 & 0.00063 \\
\hline & & & & & & co-ko & 0.03355 & 0.0023 & & & \\
\hline & & & & & & co-ma & 0.06877 & 0.00391 & & & \\
\hline & & & & & & co-ph & 0.04632 & 0.002 & & & \\
\hline & & & & & & co-ta & 003623 & 00021 & & & \\
\hline
\end{tabular}


Table 2. CPI, All Items

Estimation Using Log Distance Function, Overall Period and Subperiods, Volatility Measure 1

\begin{tabular}{|c|c|c|c|c|c|c|c|c|c|c|}
\hline Variable & Coeff. & t-stat & Coeff. & t-stat & Coeff. & t-stat & Coeff. & t-stat & Coeff. & t-stat \\
\hline & \multicolumn{2}{|c|}{$1991.01-2001.06$} & \multicolumn{2}{|c|}{$1991.01-1994.11$} & \multicolumn{2}{|c|}{$1994.12-1997.06$} & \multicolumn{2}{|c|}{$1997.07-1998.12$} & \multicolumn{2}{|c|}{$1999.01-2001.06$} \\
\hline $\ln ($ distance $)$ & 1.15 & 14.12 & 0.48 & 6.38 & 0.58 & 7.34 & 1.15 & 5.51 & 0.74 & 6.91 \\
\hline \multicolumn{11}{|c|}{ North America - North America } \\
\hline us-ca & 11.61 & 33.12 & 11.28 & 57.07 & 9.69 & 39.06 & 11.46 & 13.05 & 11.71 & 33.87 \\
\hline us-me & 53.86 & 89.35 & 13.68 & 67.32 & 82.01 & 234.42 & 39.48 & 58.80 & 21.86 & 41.91 \\
\hline ca-me & 53.61 & 303.06 & 17.83 & 48.31 & 77.84 & 257.54 & 37.57 & 139.38 & 21.14 & 73.29 \\
\hline \multicolumn{11}{|c|}{ South America - South America } \\
\hline ar-bo & 6.47 & 15.10 & 49.35 & 109.05 & 5.49 & 10.17 & 5.53 & 8.23 & . & . \\
\hline ar-br & 23.99 & 70.69 & 12.60 & 31.08 & 7.25 & 24.17 & 1.89 & 4.43 & . & . \\
\hline ar-co & 30.94 & 87.85 & 33.52 & 76.28 & 20.41 & 58.85 & 42.30 & 60.25 & . & \\
\hline bo-br & 47.93 & 113.29 & 28.81 & 59.20 & 9.88 & 19.57 & 4.32 & 6.66 & 57.35 & 69.14 \\
\hline bo-co & 32.08 & 75.22 & 7.50 & 13.59 & 22.26 & 42.05 & 42.56 & 56.27 & 32.52 & 39.84 \\
\hline br-co & 56.53 & 173.68 & 41.90 & 27.87 & 24.26 & 80.97 & 40.37 & 69.46 & 69.12 & 189.40 \\
\hline \multicolumn{11}{|c|}{ Asia - Asia } \\
\hline indi-indo & 124.93 & 422.94 & 4.30 & 15.08 & 20.05 & 72.81 & 334.14 & 414.04 & 78.05 & 121.25 \\
\hline indi-ko & 62.69 & 213.98 & 17.95 & 78.94 & 24.44 & 74.73 & 154.65 & 215.30 & 20.76 & 44.72 \\
\hline indi-ma & 40.69 & 96.16 & 7.45 & 25.86 & 17.11 & 43.96 & 93.12 & 122.00 & 4.11 & 6.39 \\
\hline indi-ph & 43.56 & 171.77 & 29.34 & 192.30 & 24.41 & 67.65 & 75.10 & 128.21 & 17.13 & 42.50 \\
\hline indi-ta & 15.56 & 46.52 & 20.38 & 17.80 & 12.34 & 30.76 & 24.02 & 34.59 & 10.88 & 21.53 \\
\hline indi-th & 56.30 & 222.06 & 40.24 & 160.52 & 21.34 & 78.50 & 121.20 & 180.04 & 23.06 & 61.49 \\
\hline indo-ko & 98.94 & 296.29 & 9.90 & 8.53 & 11.03 & 33.19 & 269.07 & 331.28 & 75.11 & 102.26 \\
\hline indo-ma & 123.61 & 309.50 & 18.18 & 61.71 & 7.19 & 18.68 & 281.86 & 406.05 & 77.23 & 102.61 \\
\hline indo-ph & 104.69 & 366.94 & 7.71 & 21.02 & 9.80 & 30.85 & 294.93 & 367.44 & 67.01 & 111.07 \\
\hline indo-ta & 163.99 & 428.69 & 17.59 & 15.23 & 7.30 & 17.91 & 322.03 & 386.44 & 74.69 & 100.89 \\
\hline indo-th & 94.22 & 308.51 & 6.59 & 5.58 & 4.06 & 13.83 & 261.31 & 356.33 & 63.03 & 101.96 \\
\hline ko-ma & 57.19 & 152.43 & 9.90 & 14.79 & 14.60 & 36.19 & 133.90 & 257.58 & 20.66 & 28.11 \\
\hline ko-ph & 48.28 & 179.76 & 18.18 & 56.52 & 21.35 & 60.88 & 129.45 & 207.75 & 23.87 & 58.87 \\
\hline ko-ta & 73.24 & 239.88 & & . & 10.47 & 28.52 & 143.71 & 223.94 & 16.48 & 37.26 \\
\hline ko-th & 42.68 & 141.71 & 7.71 & 16.90 & 7.71 & 23.16 & 100.48 & 177.44 & 25.34 & 55.83 \\
\hline ma-ph & 29.68 & 83.53 & 17.59 & 27.04 & 15.66 & 34.48 & 58.45 & 118.76 & 23.45 & 41.75 \\
\hline ma-ta & 38.24 & 86.34 & & & 10.17 & 20.81 & 77.55 & 104.24 & 12.57 & 19.15 \\
\hline ma-th & 32.83 & 83.95 & 6.59 & 8.49 & 9.37 & 21.39 & 54.35 & 128.15 & 23.25 & 40.09 \\
\hline ph-ta & 32.86 & 116.37 & & . & 7.11 & 16.80 & 59.47 & 98.96 & 23.65 & 64.43 \\
\hline ph-th & 30.59 & 119.89 & 20.17 & 46.48 & 14.95 & 45.46 & 67.06 & 126.50 & 17.38 & 47.48 \\
\hline ta-th & 56.53 & 150.77 & . & . & 4.78 & 11.86 & 103.64 & 139.85 & 25.42 & 51.06 \\
\hline \multicolumn{11}{|c|}{ Asia - Pacific } \\
\hline indi-ja & 47.55 & 187.00 & 10.43 & 8.14 & 50.43 & 136.21 & 41.97 & 70.18 & 29.74 & 62.82 \\
\hline indo-ja & 122.39 & 419.36 & 21.22 & 66.30 & 50.72 & 176.56 & 319.05 & 434.43 & 92.72 & 137.21 \\
\hline ja-ko & 69.45 & 474.40 & 20.17 & 65.93 & 46.28 & 225.91 & 171.52 & 609.94 & 40.09 & 192.65 \\
\hline ja-ma & 53.93 & 154.41 & 20.38 & 31.70 & 51.64 & 128.86 & 87.85 & 212.41 & 37.75 & 61.62 \\
\hline ja-ph & 54.70 & 250.25 & 40.24 & 141.38 & 63.39 & 198.52 & 81.90 & 162.51 & 52.89 & 158.33 \\
\hline ja-ta & 33.77 & 124.81 & & & 33.05 & 93.78 & 39.13 & 77.72 & 32.95 & 76.46 \\
\hline ja-th & 58.57 & 221.29 & 21.22 & 49.82 & 47.01 & 143.66 & 123.21 & 260.85 & 53.06 & 134.88 \\
\hline
\end{tabular}


Table 2 continued...

\begin{tabular}{|c|c|c|c|c|c|c|c|c|c|c|}
\hline Variable & Coeff. & t-stat & Coeff. & t-stat & Coeff. & t-stat & Coeff. & t-stat & Coeff. & t-stat \\
\hline & \multicolumn{2}{|c|}{$1991.01-2001.06$} & \multicolumn{2}{|c|}{$1991.01-1994.11$} & \multicolumn{2}{|c|}{$1994.12-1997.06$} & \multicolumn{2}{|c|}{$1997.07-1998.12$} & \multicolumn{2}{|c|}{$1999.01-2001.06$} \\
\hline \multicolumn{11}{|c|}{ North America - South America } \\
\hline us-ar & 8.44 & 13.93 & 13.33 & 27.43 & 0.29 & 0.69 & -2.78 & -2.66 & & \\
\hline us-bo & 4.19 & 5.45 & 4.36 & 10.40 & 6.77 & 11.60 & 5.32 & 4.05 & 2.82 & 2.35 \\
\hline us-br & 50.72 & 67.98 & 24.14 & 28.31 & 9.86 & 29.09 & 1.66 & 1.85 & 58.49 & 74.13 \\
\hline us-co & 31.36 & 65.25 & 27.22 & 84.36 & 21.55 & 67.34 & 47.95 & 37.81 & 34.09 & 85.76 \\
\hline ca-ar & 14.47 & 45.01 & 11.37 & 27.71 & 6.66 & 21.52 & 8.54 & 14.69 & 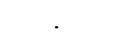 & . \\
\hline ca-bo & 11.97 & 28.78 & 29.20 & 70.46 & 12.40 & 23.51 & 14.37 & 20.39 & 10.66 & 12.35 \\
\hline$c a-b r$ & 53.24 & 196.89 & 36.07 & 117.20 & 15.89 & 62.26 & 7.78 & 19.53 & 57.01 & 155.11 \\
\hline ca-co & 36.63 & 135.31 & 50.41 & 163.41 & 24.65 & 88.82 & 46.65 & 83.94 & 39.49 & 107.11 \\
\hline me-ar & 61.68 & 187.66 & 34.80 & 81.79 & 77.17 & 162.66 & 37.70 & 63.40 & . & . \\
\hline me-bo & 58.58 & 146.01 & 43.06 & 149.76 & 79.78 & 127.97 & 38.13 & 53.70 & 19.08 & 22.73 \\
\hline me-br & 78.67 & 262.84 & 48.21 & 141.73 & 79.64 & 208.45 & 34.98 & 81.75 & 60.66 & 156.94 \\
\hline me-co & 65.54 & 234.88 & 12.71 & 42.73 & 80.78 & 205.37 & 44.21 & 84.00 & 36.45 & 103.09 \\
\hline \multicolumn{11}{|c|}{ North America - Asia } \\
\hline us-indi & 26.50 & 57.40 & 43.46 & 120.62 & 22.72 & 53.87 & 13.08 & 10.59 & 2.99 & 5.89 \\
\hline us-indo & 120.23 & 124.75 & 2.40 & 7.33 & 1.47 & 3.99 & 347.99 & 131.96 & 72.75 & 68.37 \\
\hline us-ko & 58.54 & 134.30 & 3.12 & 8.26 & 13.32 & 28.40 & 173.60 & 190.34 & 22.62 & 31.69 \\
\hline us-ma & 41.32 & 41.28 & 7.76 & 6.12 & 9.58 & 19.93 & 100.80 & 33.88 & -0.54 & -0.58 \\
\hline us-ph & 32.66 & 77.10 & 18.18 & 47.27 & 9.33 & 21.43 & 79.96 & 74.27 & 20.45 & 39.69 \\
\hline us-ta & 18.73 & 38.81 & 4.36 & 9.98 & 7.11 & 14.92 & 37.22 & 37.50 & 13.17 & 18.72 \\
\hline us-th & 46.79 & 65.01 & 17.57 & 109.59 & 4.30 & 10.63 & 127.92 & 42.10 & 23.16 & 35.88 \\
\hline ca-indi & 31.36 & 122.26 & 8.42 & 29.81 & 21.39 & 71.49 & 15.66 & 24.95 & 10.52 & 23.37 \\
\hline ca-indo & 123.99 & 383.90 & 32.43 & 122.80 & 6.62 & 22.70 & 350.88 & 452.54 & 70.95 & 94.51 \\
\hline ca-ko & 58.02 & 194.24 & 19.59 & 17.01 & 11.62 & 34.93 & 167.00 & 277.36 & 18.82 & 36.19 \\
\hline ca-ma & 42.93 & 113.76 & 19.91 & 59.54 & 11.75 & 28.41 & 101.68 & 196.47 & 11.08 & 16.33 \\
\hline ca-ph & 34.14 & 120.01 & 12.03 & 34.34 & 16.09 & 44.15 & 76.89 & 124.04 & 22.98 & 46.05 \\
\hline ca-ta & 19.70 & 51.81 & 17.57 & 51.00 & 10.55 & 25.58 & 34.70 & 48.89 & 16.72 & 27.95 \\
\hline ca-th & 48.65 & 159.47 & 14.77 & 36.30 & 7.09 & 20.61 & 128.46 & 230.77 & 21.12 & 41.02 \\
\hline me-indi & 60.89 & 190.57 & 36.81 & 125.16 & 73.47 & 164.01 & 42.27 & 63.38 & 19.98 & 38.02 \\
\hline me-indo & 141.15 & 388.20 & 16.00 & 44.49 & 75.75 & 177.85 & 367.42 & 446.96 & 74.40 & 94.97 \\
\hline me-ko & 84.43 & 238.67 & 22.76 & 65.64 & 81.25 & 178.45 & 176.43 & 258.22 & 31.24 & 54.34 \\
\hline me-ma & 85.46 & 208.81 & 17.53 & 46.65 & 75.89 & 146.32 & 130.47 & 232.00 & 20.77 & 29.11 \\
\hline me-ph & 63.59 & 188.93 & 7.13 & 13.38 & 69.13 & 141.25 & 89.21 & 131.38 & 29.96 & 56.43 \\
\hline me-ta & 31.56 & 75.85 & 35.41 & 76.59 & 11.88 & 20.81 & 53.59 & 69.96 & 28.71 & 44.90 \\
\hline me-th & 78.78 & 224.17 & 34.12 & 82.99 & 79.30 & 175.76 & 147.63 & 233.58 & 32.94 & 60.09 \\
\hline \multicolumn{11}{|c|}{ North America - Pacific } \\
\hline us-ja & 42.46 & 69.86 & 27.05 & 88.70 & 57.52 & 116.45 & 65.94 & 42.41 & 38.01 & 77.68 \\
\hline ca-ja & 43.49 & 180.27 & 12.90 & 39.70 & 54.02 & 186.14 & 60.18 & 121.21 & 39.46 & 86.78 \\
\hline me-ja & 73.15 & 247.24 & 22.50 & 19.81 & 99.77 & 232.89 & 83.29 & 149.41 & 46.89 & 97.43 \\
\hline
\end{tabular}


Table 2 continued...

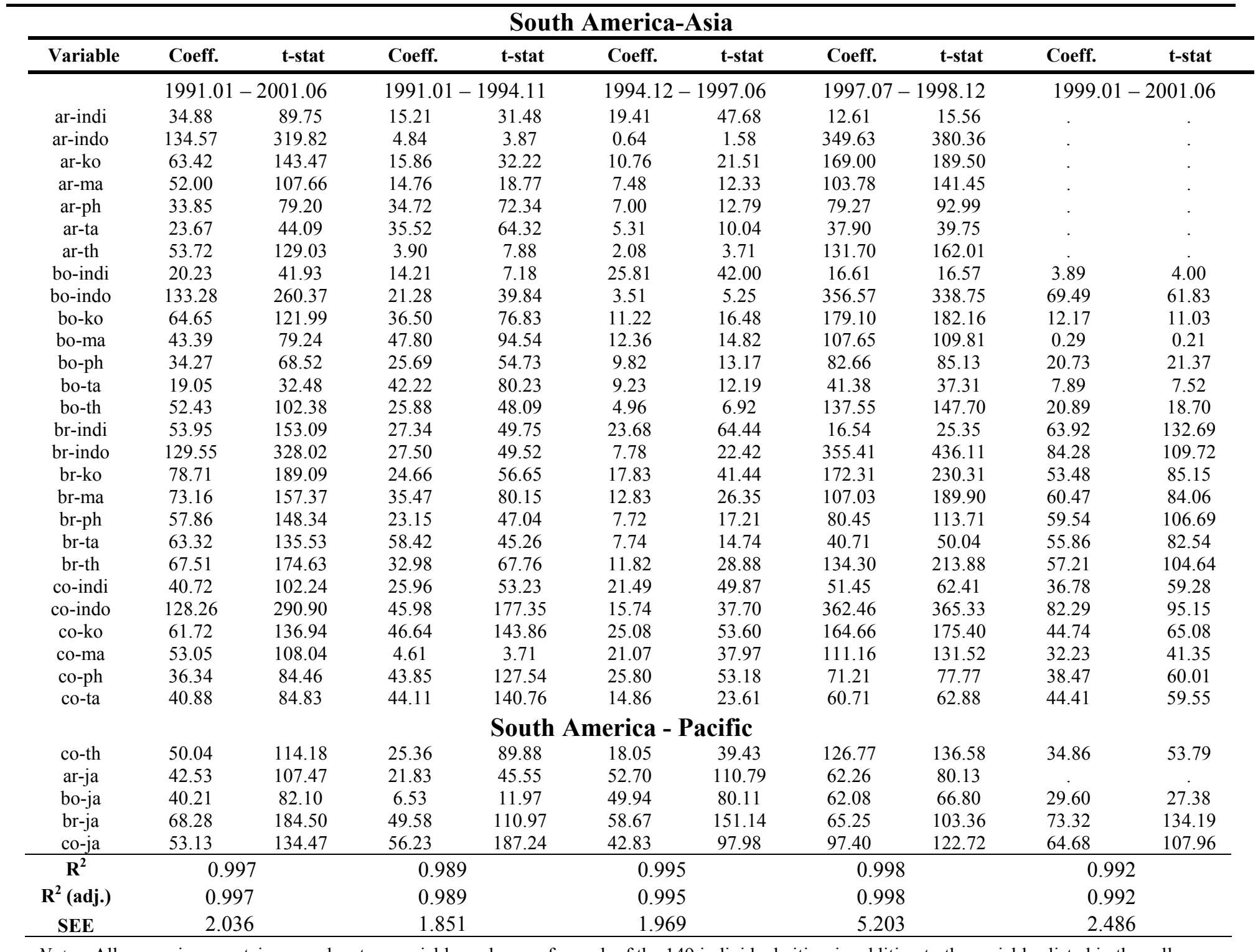

Notes: All regressions contain as explanatory variables a dummy for each of the 149 individual cities, in addition to the variables listed in the cell.

Coefficients on log distance, border and SSE are multiplied by 103 . The dependent variable is the standard deviation of the two-months difference in relative prices. There are 11026 observations. (Exceptions: No Taiwanese data are available for the first subperiod, no Argentinean data are available for the last subperiod). 
Table 3:

Estimation Using Log Distance, Border, Exchange Rate Volatility and Various Dummy Variables Overall Period (Jan 1991 - June 2001), Measure 1

\begin{tabular}{|c|c|c|c|c|c|c|c|c|c|c|}
\hline Specification & (1) & $(2)$ & (3) & (4) & $(5)$ & $(6)$ & (7) & $(8)$ & $(9)$ & $(10)$ \\
\hline Variable & $\begin{array}{l}\text { Coeff. } \\
\text { (Stdv.) }\end{array}$ & $\begin{array}{l}\text { Coeff. } \\
\text { (Stdv.) }\end{array}$ & $\begin{array}{l}\text { Coeff. } \\
\text { (Stdv.). }\end{array}$ & $\begin{array}{l}\text { Coeff. } \\
\text { (Stdv.) }\end{array}$ & $\begin{array}{l}\text { Coeff. } \\
\text { (Stdv.) }\end{array}$ & $\begin{array}{l}\text { Coeff. } \\
\text { (Stdv.) }\end{array}$ & $\begin{array}{l}\text { Coeff. } \\
\text { (Stdv.) }\end{array}$ & $\begin{array}{l}\text { Coeff. } \\
\text { (Stdv.) }\end{array}$ & $\begin{array}{l}\text { Coeff. } \\
\text { (Stdv.) }\end{array}$ & $\begin{array}{l}\text { Coeff. } \\
\text { (Stdv.) }\end{array}$ \\
\hline Log (Distance) & $\begin{array}{c}3.34 \\
(0.23)\end{array}$ & $\begin{array}{c}2.63 \\
(0.20)\end{array}$ & --- & $\begin{array}{c}2.63 \\
(0.22)\end{array}$ & $\begin{array}{c}2.16 \\
(0.22)\end{array}$ & --- & --- & --- & --- & --- \\
\hline Border & $\begin{array}{l}65.57 \\
(1.90)\end{array}$ & $\begin{array}{l}29.06 \\
(1.69)\end{array}$ & --- & $\begin{array}{l}29.02 \\
(1.73)\end{array}$ & $\begin{array}{l}30.66 \\
(1.76)\end{array}$ & --- & --- & --- & --- & --- \\
\hline $\begin{array}{l}\text { Nom. Exrate } \\
\text { Volatility }\end{array}$ & --- & $\begin{array}{c}0.354 \\
(0.0256)\end{array}$ & --- & $\begin{array}{c}0.354 \\
(0.0256)\end{array}$ & $\begin{array}{c}0.352 \\
(0.0257)\end{array}$ & --- & --- & --- & --- & --- \\
\hline Adjacency & --- & --- & --- & --- & --- & --- & --- & --- & --- & --- \\
\hline Float & --- & --- & --- & --- & --- & --- & --- & --- & --- & --- \\
\hline NAFTA & --- & --- & --- & $\begin{array}{c}0.14 \\
(0.52)\end{array}$ & $\begin{array}{l}-0.37 \\
(0.52)\end{array}$ & --- & --- & --- & --- & --- \\
\hline ASEAN & --- & --- & --- & --- & $\begin{array}{l}-6.71 \\
(0.89)\end{array}$ & --- & --- & --- & --- & --- \\
\hline ASEAN (w.o. Indonesia) & --- & --- & --- & --- & --- & --- & --- & --- & --- & --- \\
\hline ASEAN + Korea & --- & --- & --- & --- & --- & --- & --- & --- & --- & --- \\
\hline ASEAN + India & --- & --- & --- & --- & --- & --- & --- & --- & --- & --- \\
\hline $\begin{array}{c}\text { ASEAN (w.o. Indonesia) }+ \\
\text { Korea }\end{array}$ & --- & --- & --- & --- & --- & --- & --- & --- & --- & --- \\
\hline $\mathrm{R}^{2}$ & 0.810 & 0.866 & --- & 0.866 & 0.867 & --- & --- & --- & --- & --- \\
\hline $\mathrm{R}^{2}(\operatorname{adj})$ & 0.807 & 0.864 & --- & 0.864 & 0.865 & --- & --- & --- & --- & --- \\
\hline SEE & 17.25 & 14.47 & --- & 14.47 & 14.44 & --- & --- & --- & --- & --- \\
\hline
\end{tabular}

Heteroscedasticity-consistent standard errors (White, 1980) are reported. Coefficients, standard errors and SSE are multiplied by $10^{3}$. The dependent variable is the standard deviation of the

two-month difference in relative prices. For some countries data are not available for the overall period (see Table 1 of the Appendix for details). All regressions are based on 11026 observations. 
Figure 1:

Selected National CPI Inflation Rates and Regional Inflation Diversity, Overall Sample Period (1991.I-2001.VI)

(a) United States

Inflation Rate (12month changes) for usa

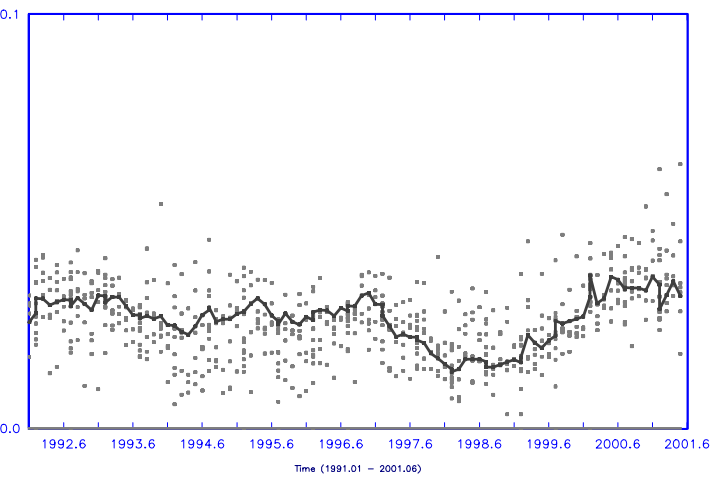

(c) Mexico

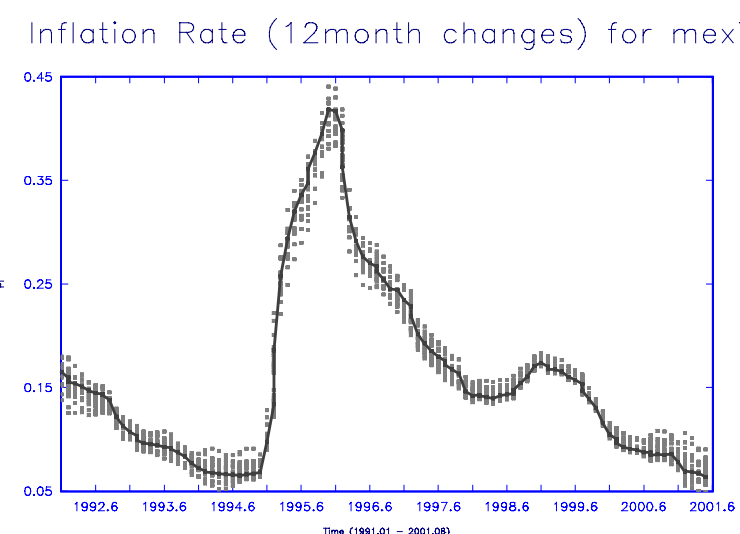

(e) Bolivia

Inflation Rate (12month changes) for colo

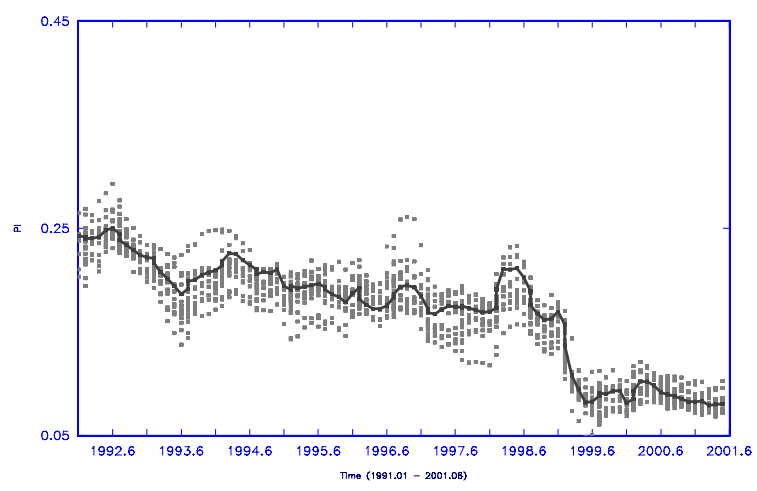

(b) Canada

Inflation Rate (12month changes) for cana

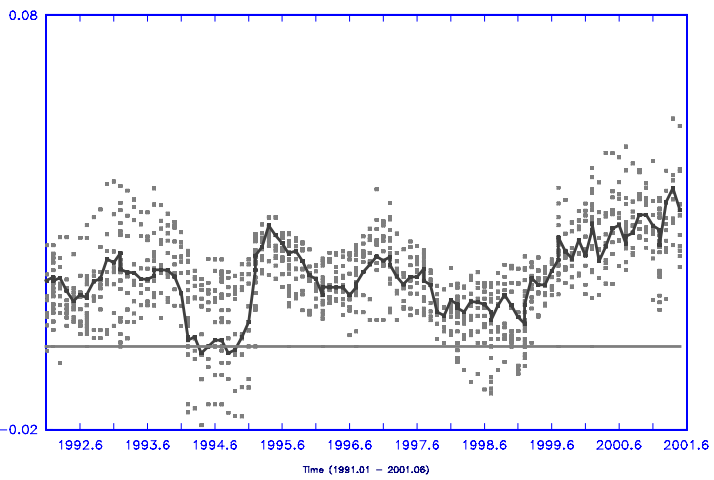

(d) Brasil

Inflation Rate (12month changes) for braz

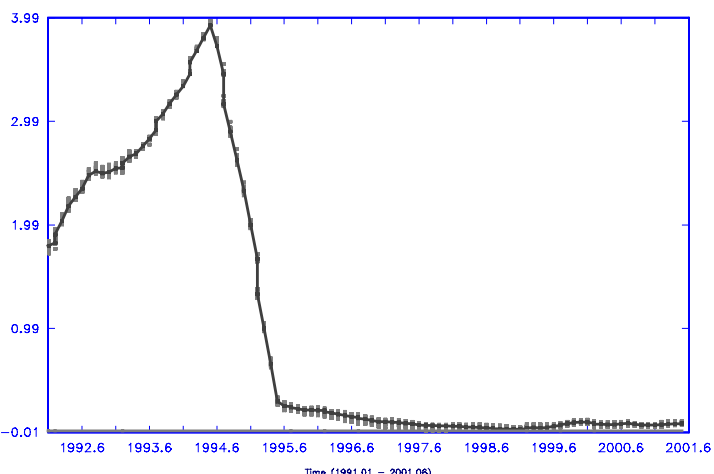

(f) Argentina

Inflation Rate (12month changes) for arge

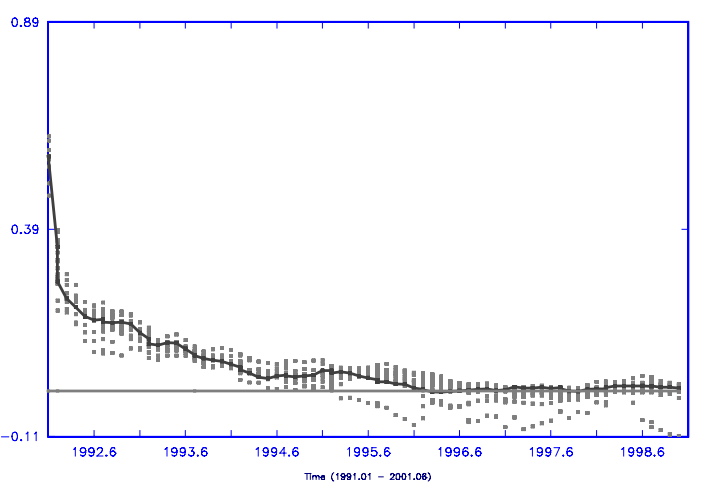




\section{Figure 1 continued...}

(g) Japan

Inflation Rate (12month changes) for jopa

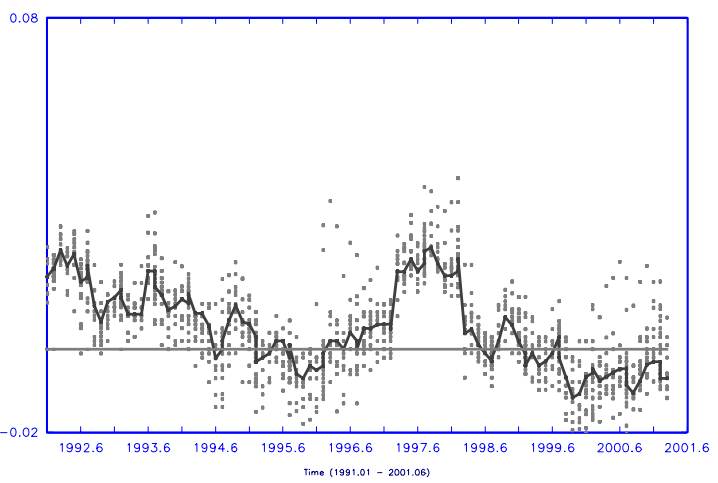

(i) Korea

Inflation Rate (12month changes) for kore

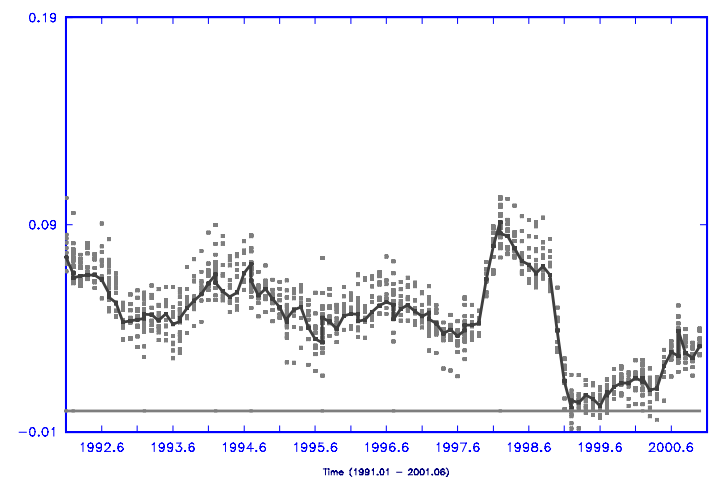

(k) Indonesia

Inflation Rate (12month changes) for indo

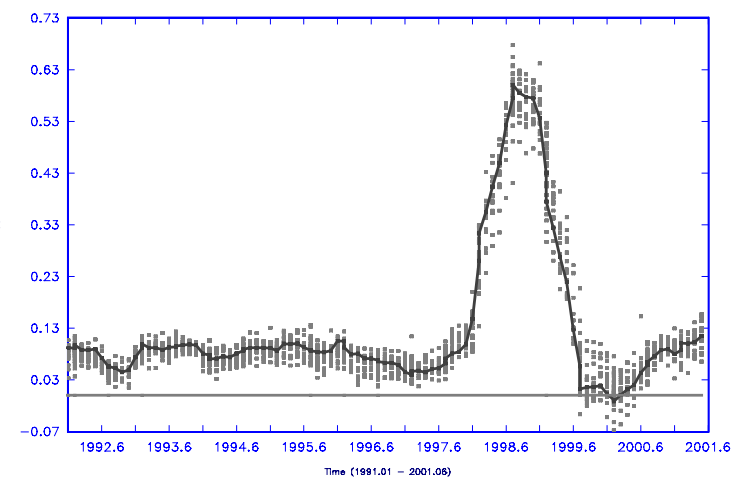

(h) India

Inflation Rate (12month changes) for indi

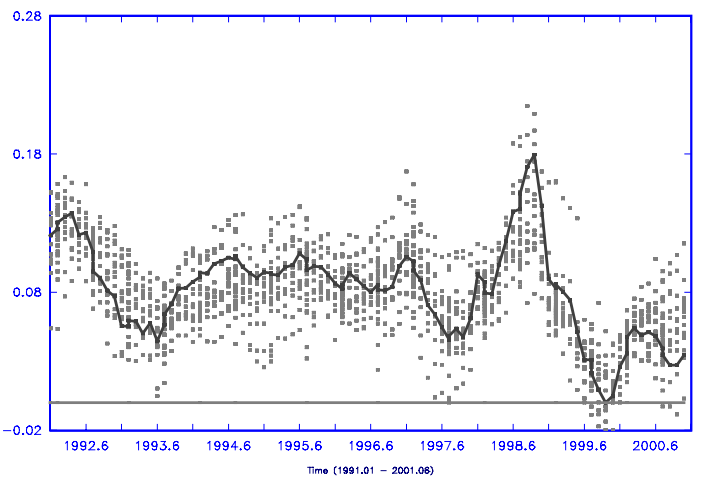

(j) Thailand

Inflation Rate (12month changes) for thai

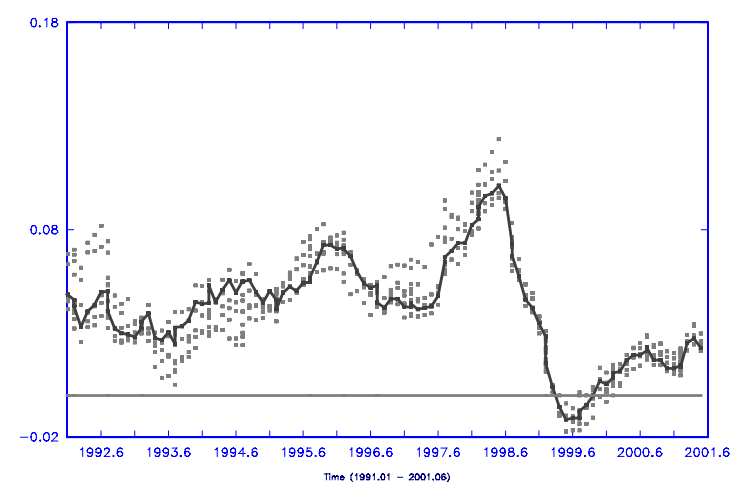

(1) Phillipines

Inflation Rate (12month changes) for phil

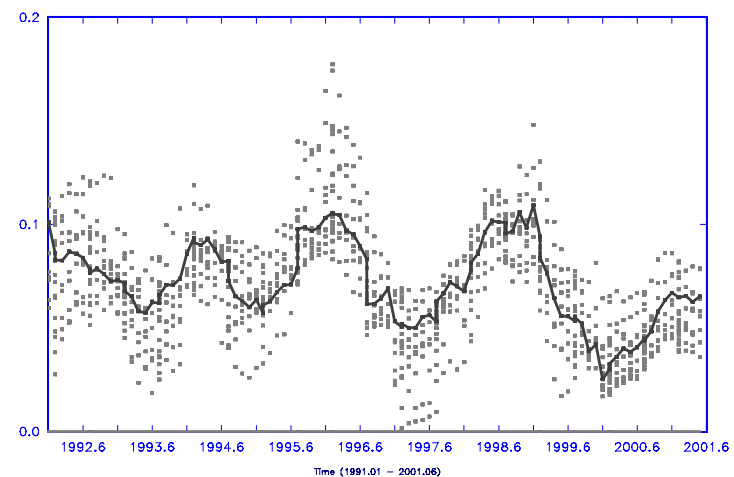


Figure 2:

\section{Intra-national, Intra-continental and Intercontinental Relative Price Volatility, Pre-crises Period (1991.I-1994.XI)}

(a) Intra-national

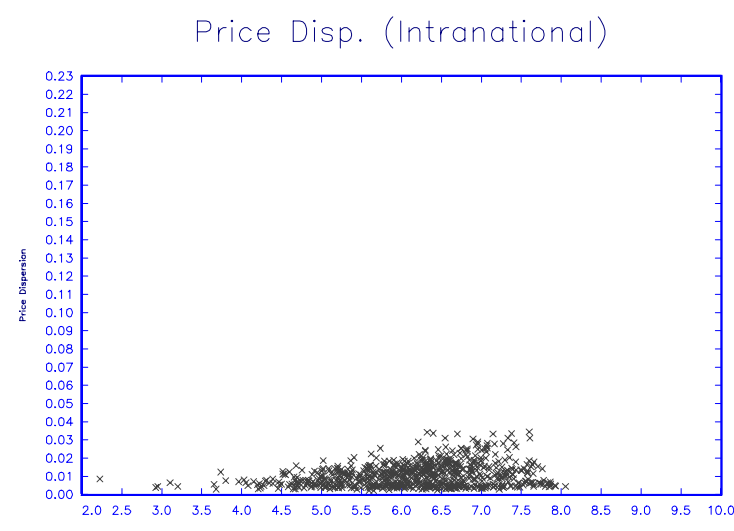

(c) South America, Intra-continental

Price Disp. (SouthAmerica-SouthAmerica)

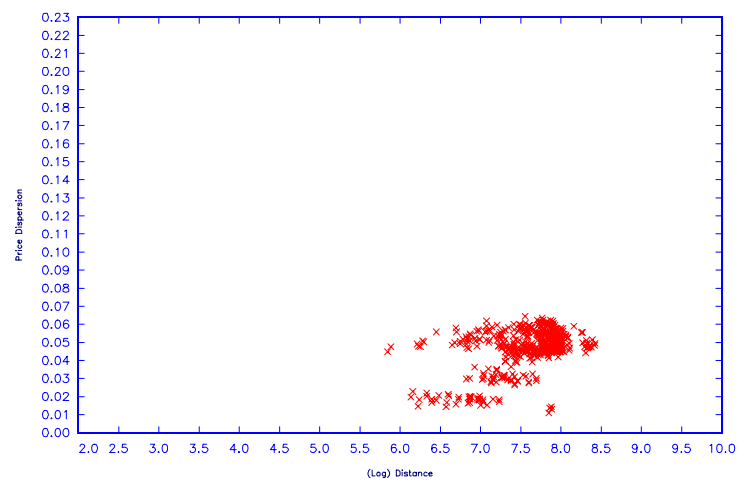

(e) Pacific, Intra-continental

Price Disp. (Pacific-Pacific)

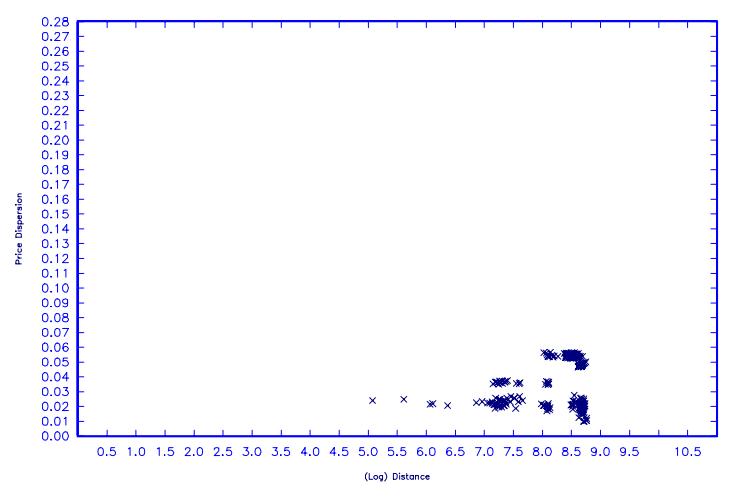

(b) North America, Intra-continental

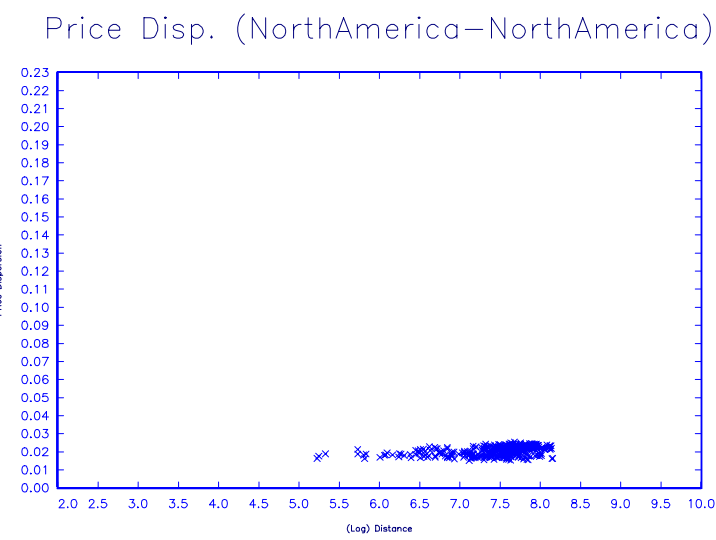

(d) Asia, Intra-continental

Price Disp. (Asia-Asia)

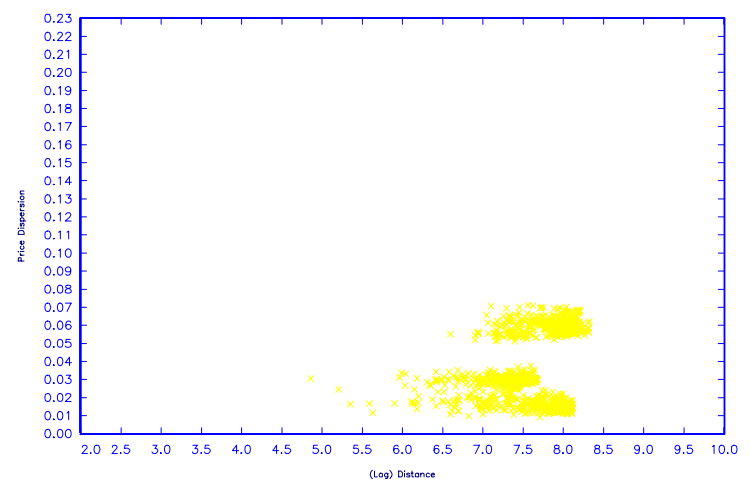

(f) Europe, Intra-continental

Price Disp. (Euro-Euro)

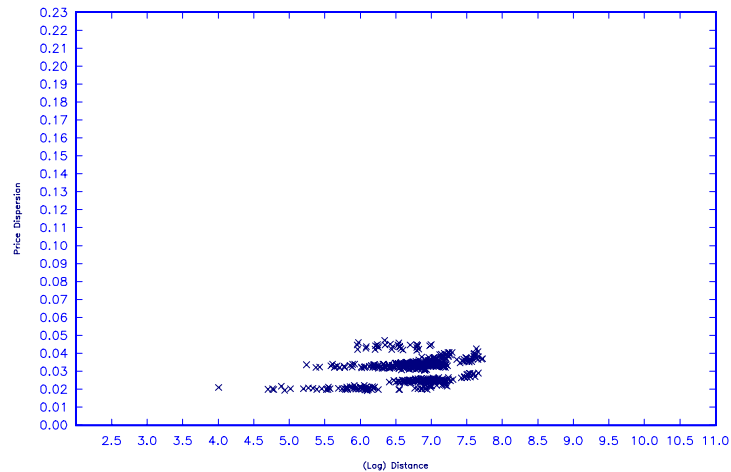




\section{Figure 2 continued...}

(g) North America versus South America

Price Disp. (NorthAmerica-SouthAmerica)

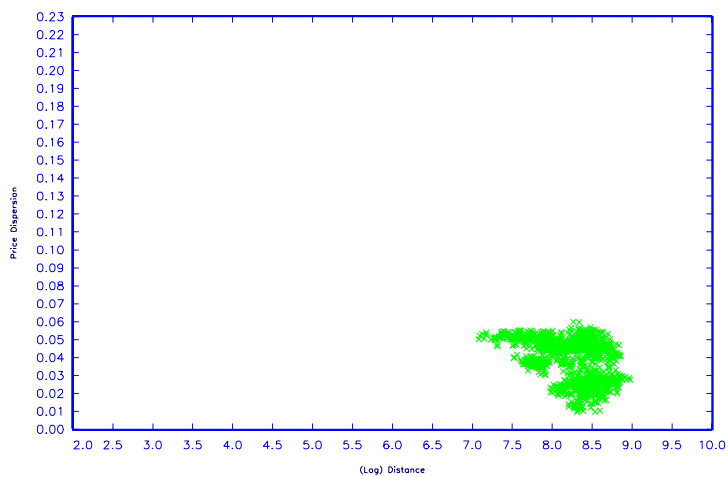

(i) North America versus Pacific

Price Disp. (North America - Pacific)

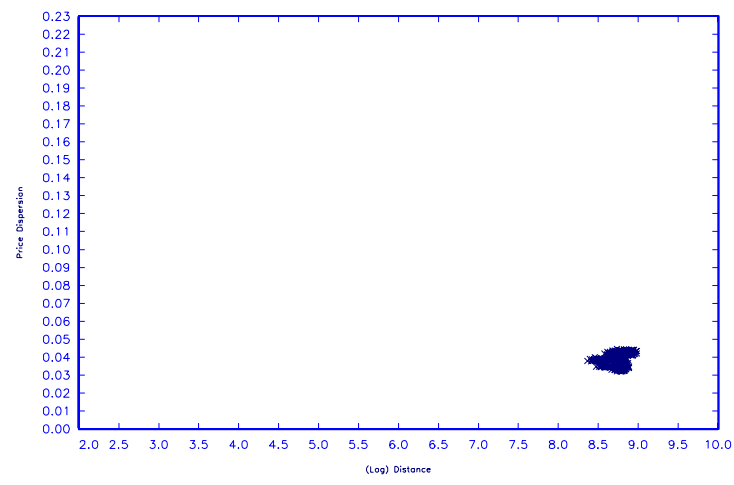

(k) South America versus Pacific

Price Disp. (SouthAmerica-Pacific)

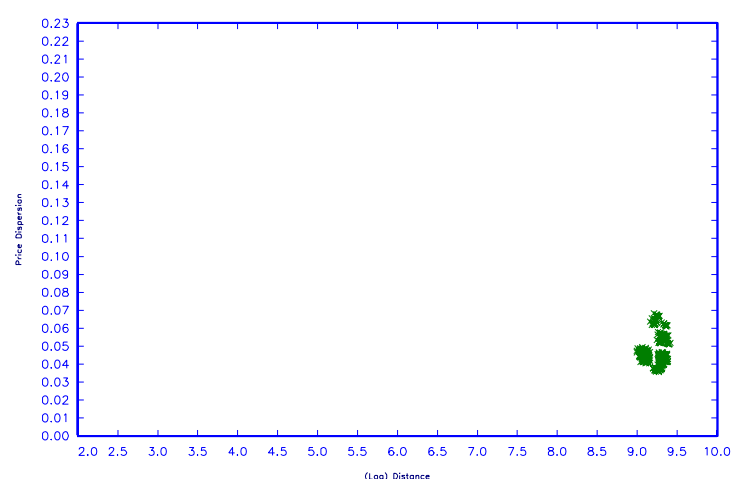

(h) North America versus Asia

Price Disp. (NorthAmerica-Asia)

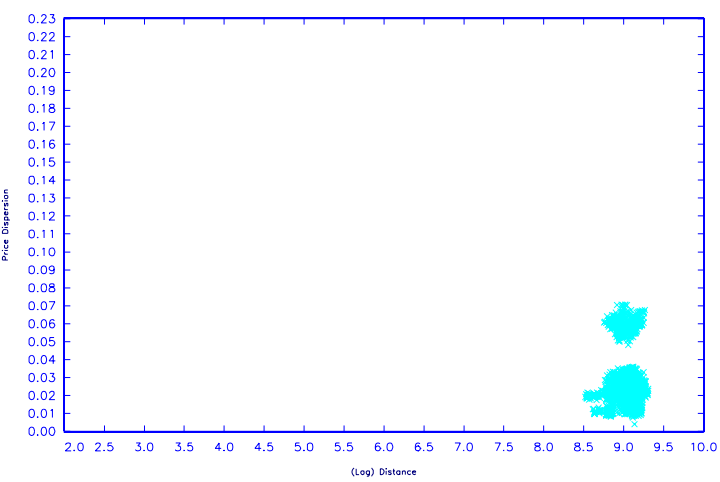

(j) South America versus Asia

Price Disp. (SouthAmerica-Asia)

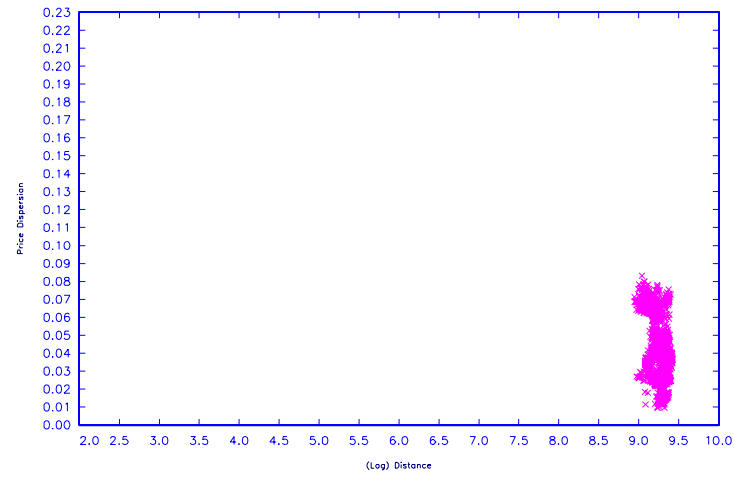

(1) Asia versus Pacific

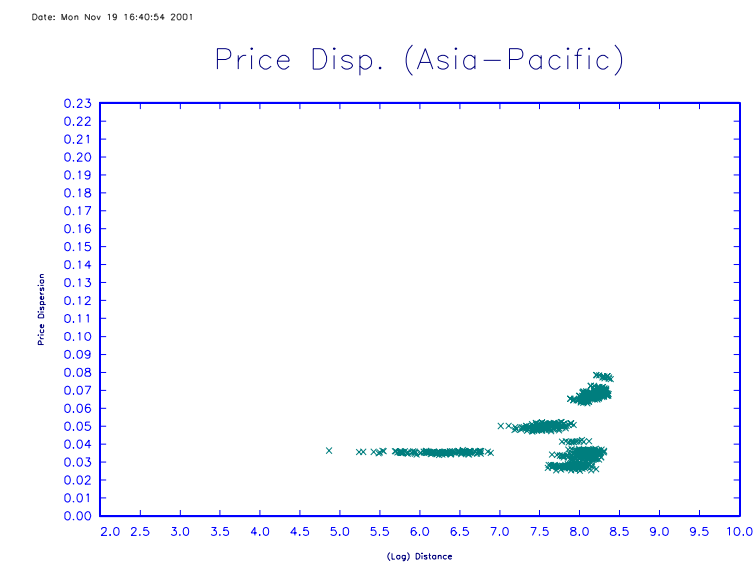


Figure 3:

Relative Price Volatility and Distance

During Selected Sub-periods

(a) Pre-Crises Period (1991.I-1994.XI)

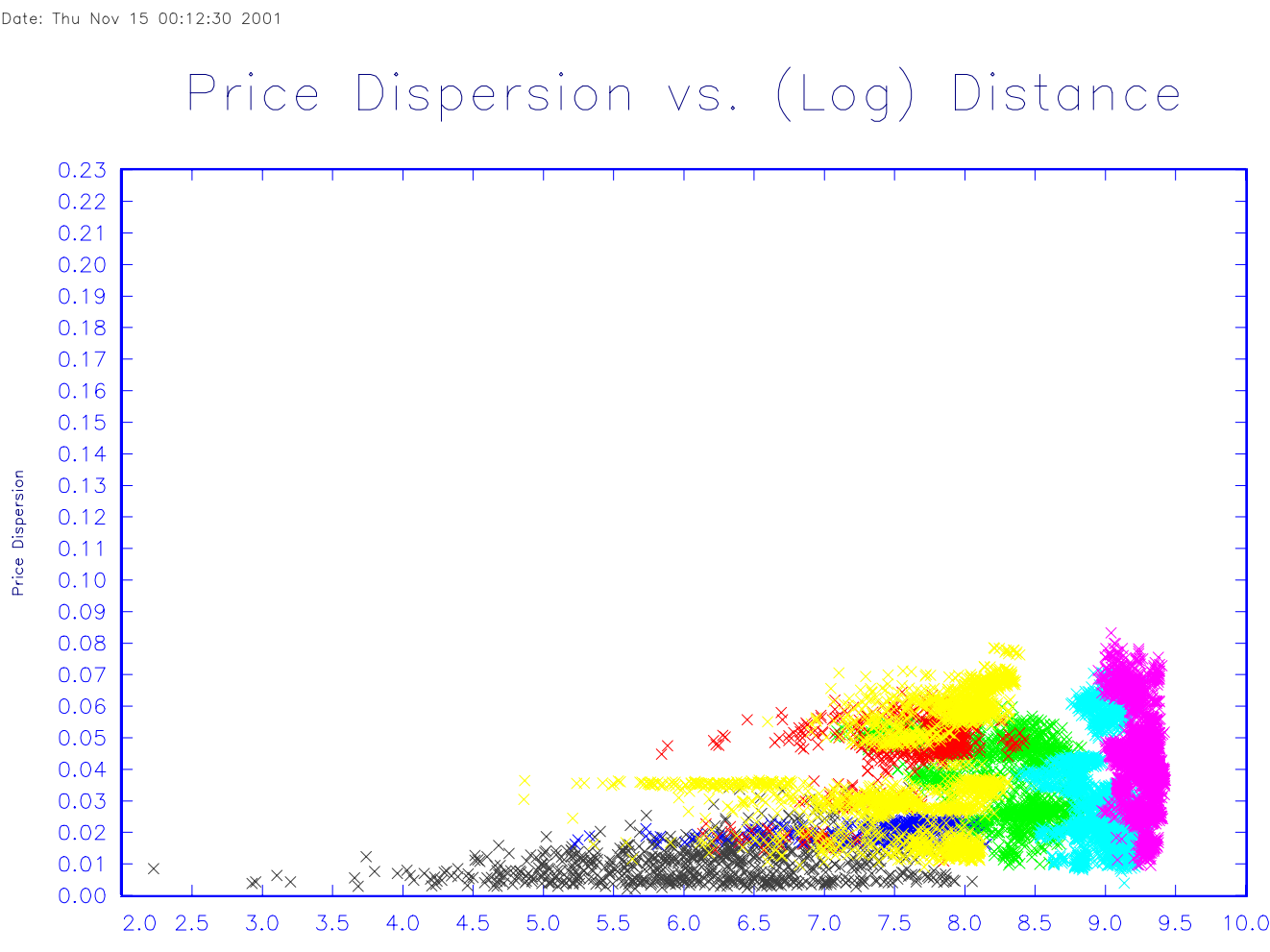

(b) Post-Mexican-Crisis Period (1994.XII-1997.VI)
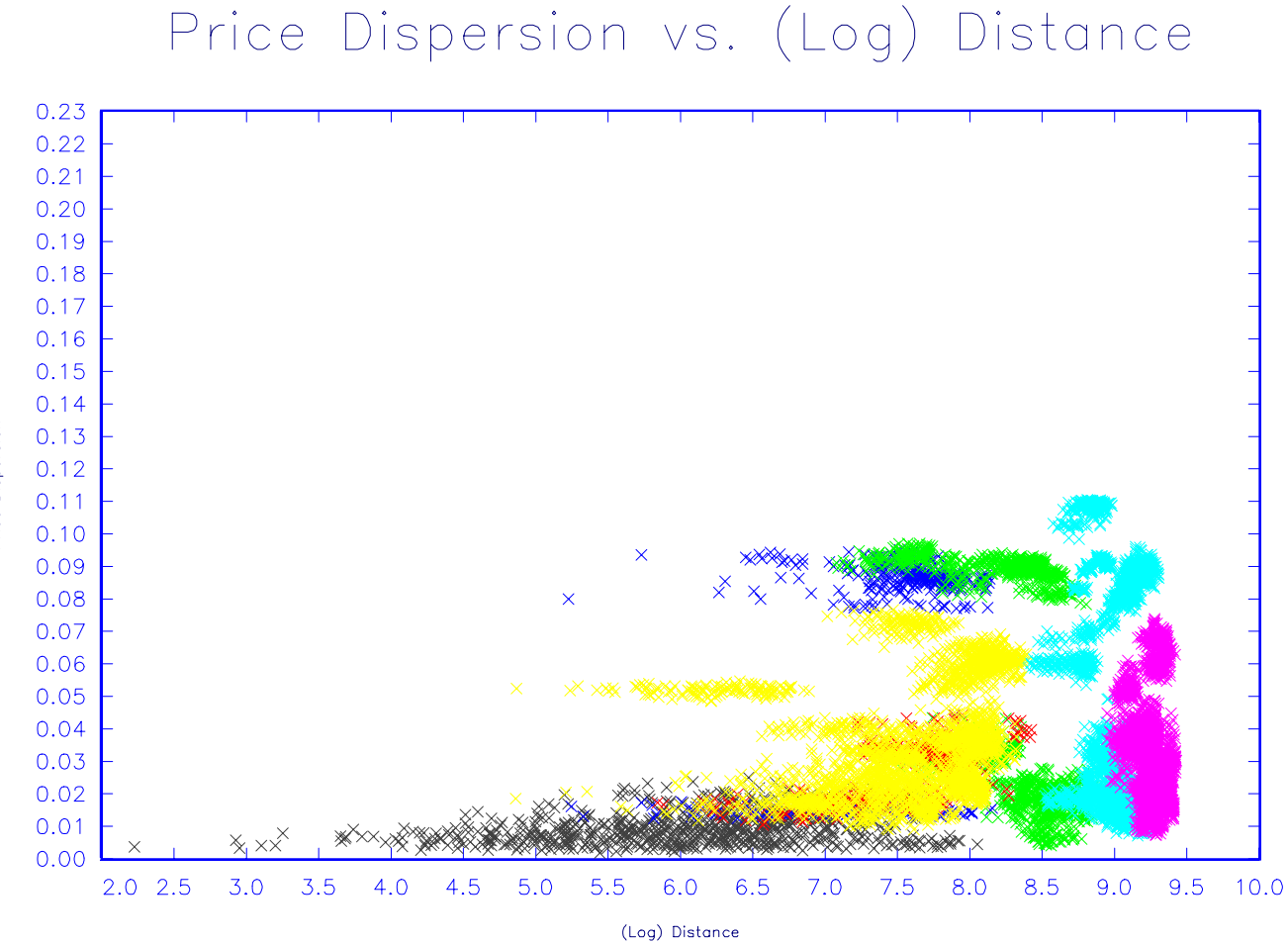


\section{Figure 3 continued...}

(c) Post-Asian-Crisis Period (1997.VII-1998.XII)
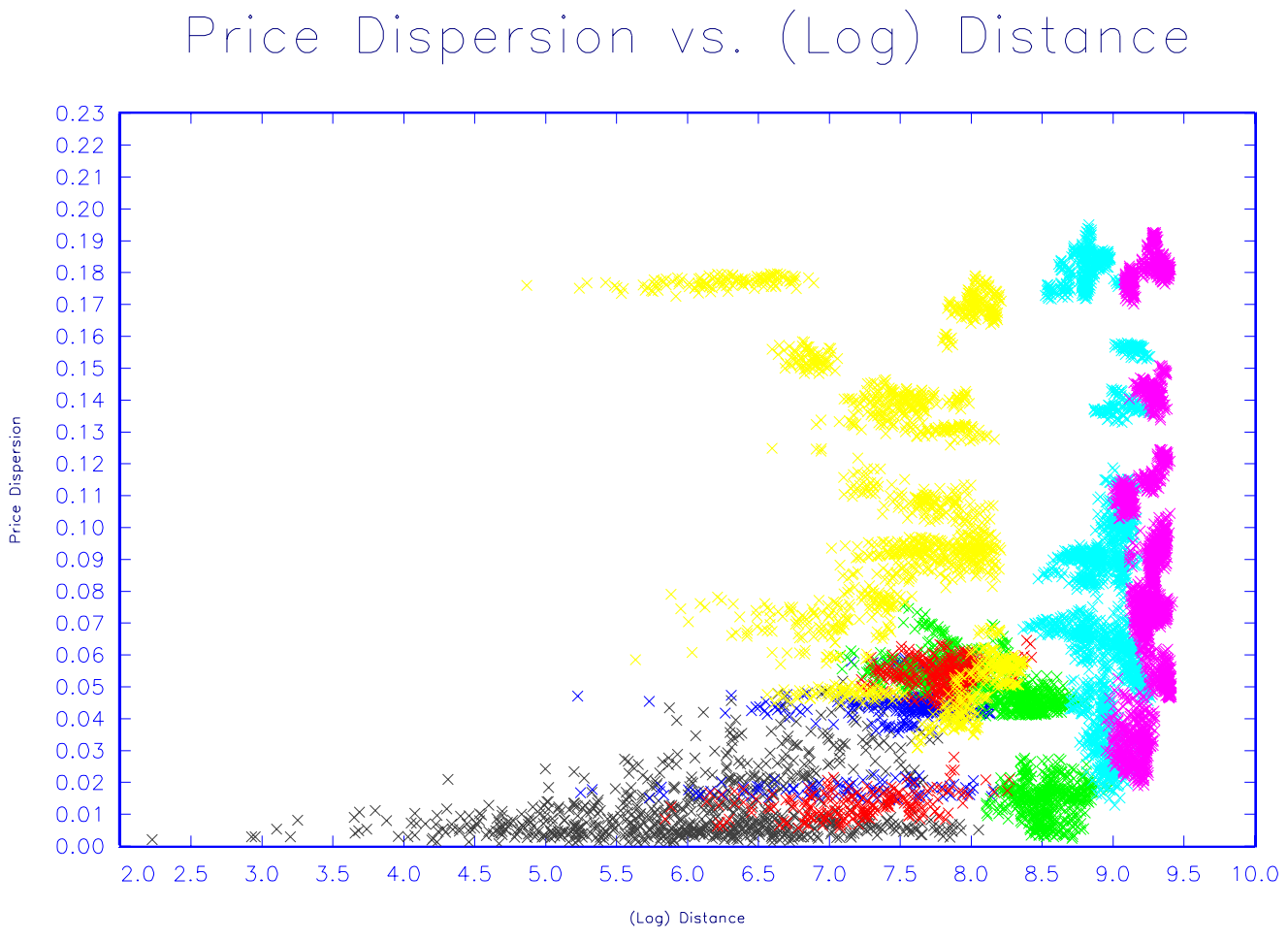

(d) Post-Brasilian-Crisis Period (1999.I-2001.VI)

Price Dispersion vs. (Log) Distance

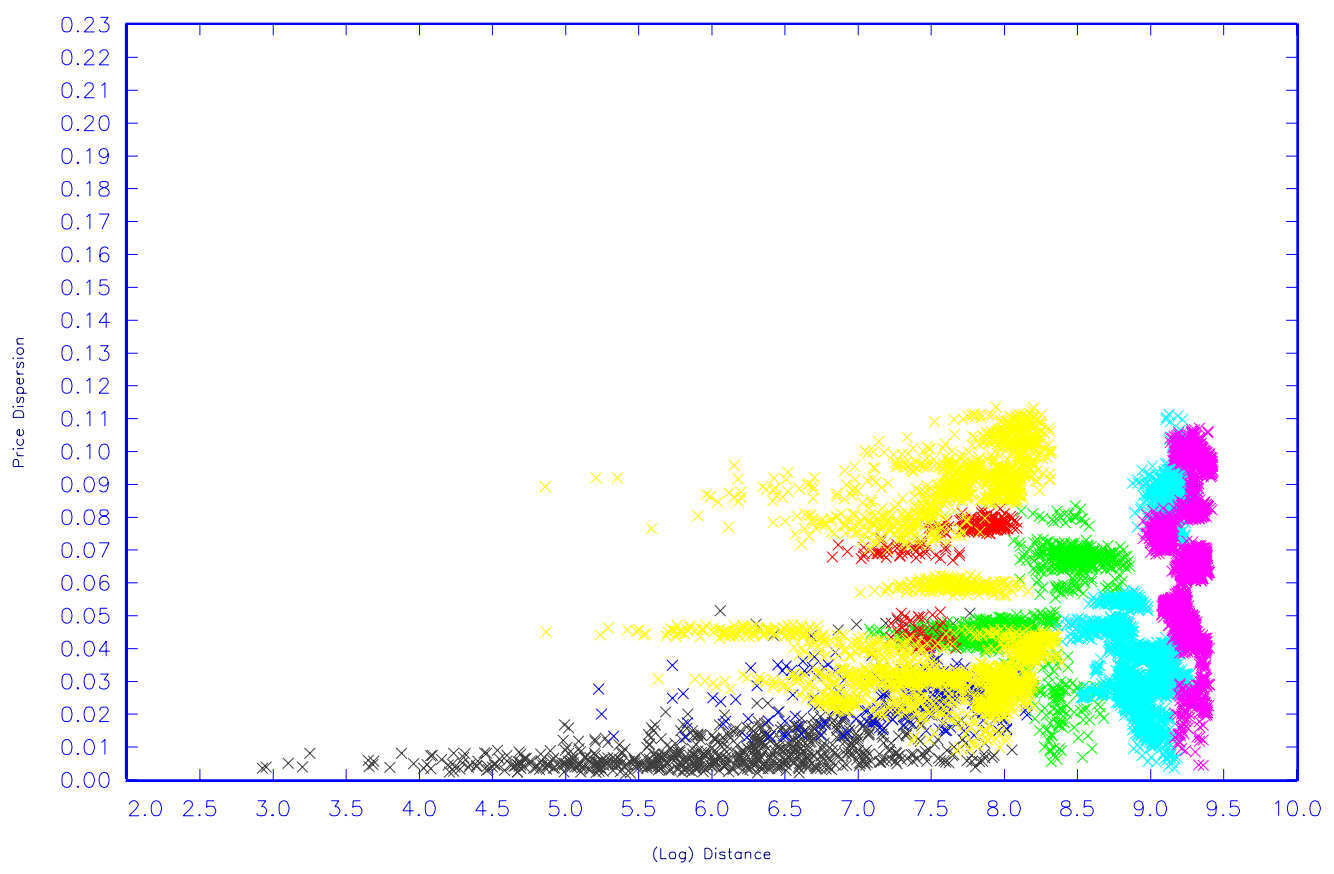




\section{Figure 4:}

\section{Between-Country Price Dispersion in Selected Subperiods:}

(a) Pre-crisis period (1991.I-1994.XI) vs. Mexican-crisis period (1994.XII-1997.VI)

(a) Pre-Crisis Period (1991.I-1994.XI) vs. Mexican-Crisis Period (1994.XII-1997.VI)

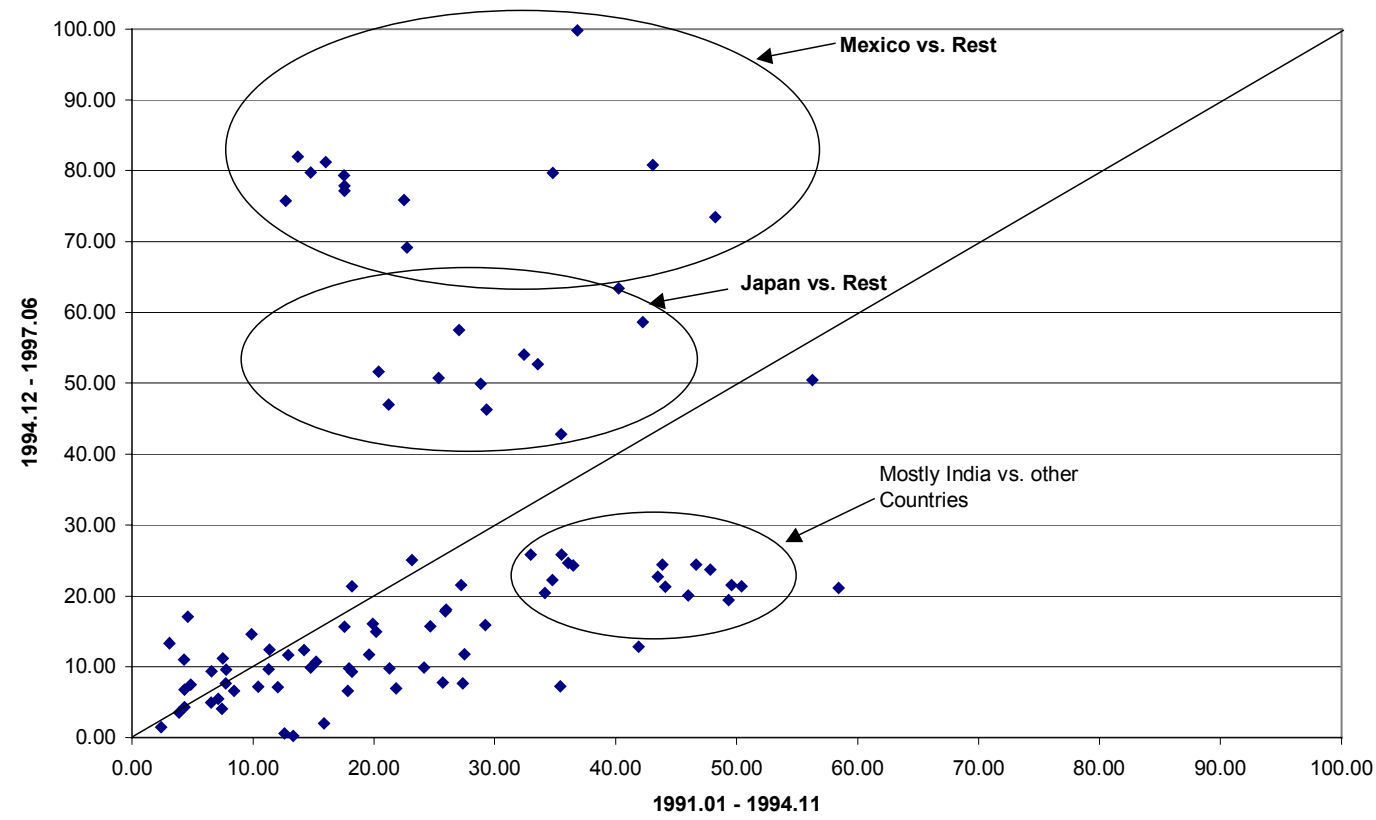

(b) Mexican-crisis period (1994.XII-1997.VI) vs. Asian Crisis Period (1997.VI-1998.XII)

(b) Mexican-Crisis Period (1994.XII - 1997.VI) vs. Asian-Crisis Period (1997.VII - 1998.XII)

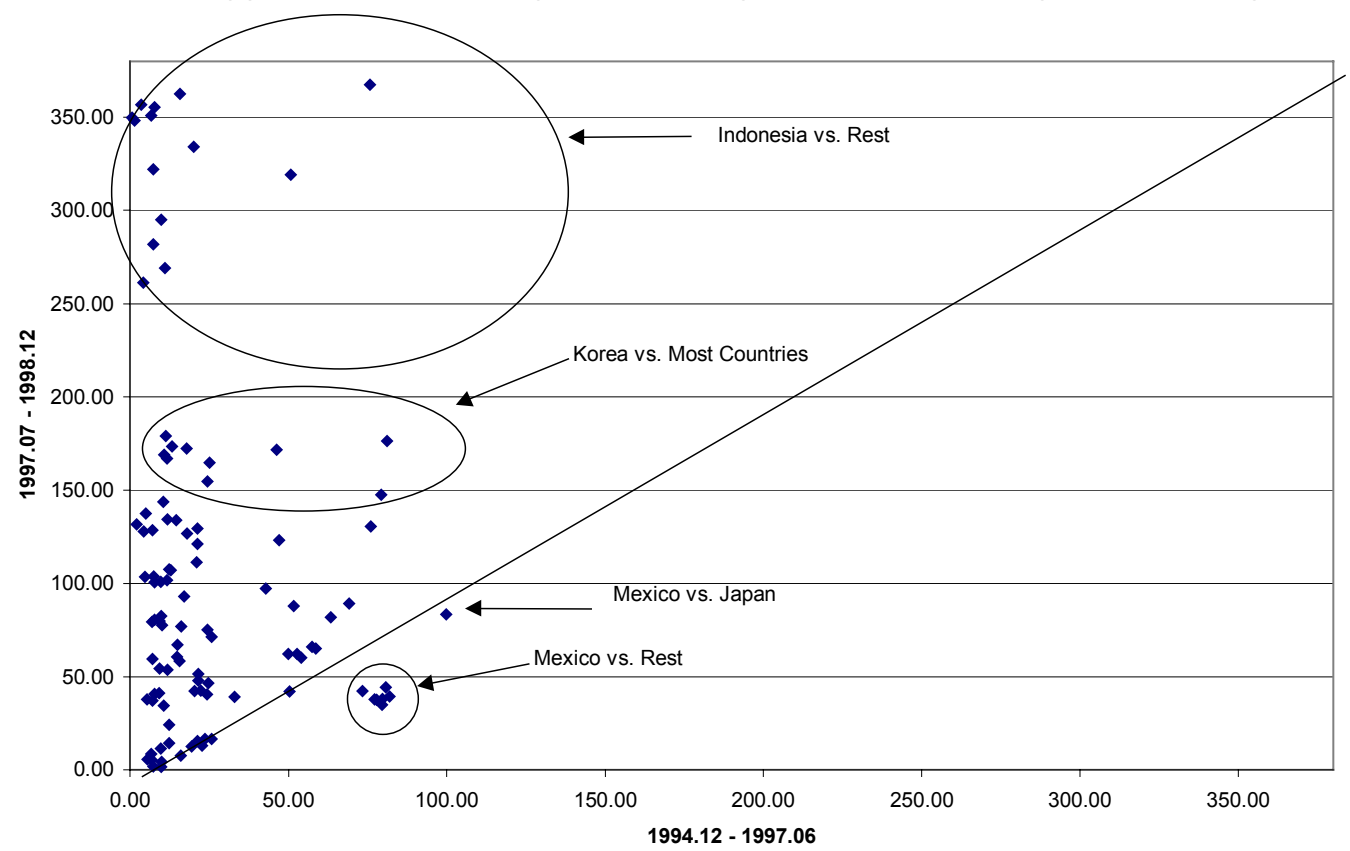

Source: own calculations 
Figure 5:

Within-Country Price Dispersion in Selected Subperiods

(a) Mexican-crisis period (1994.XII-1997.VI) vs Asian Crisis Period (1997.VI-1998.XII)

9497 vs 9798: Within Country Dispersion

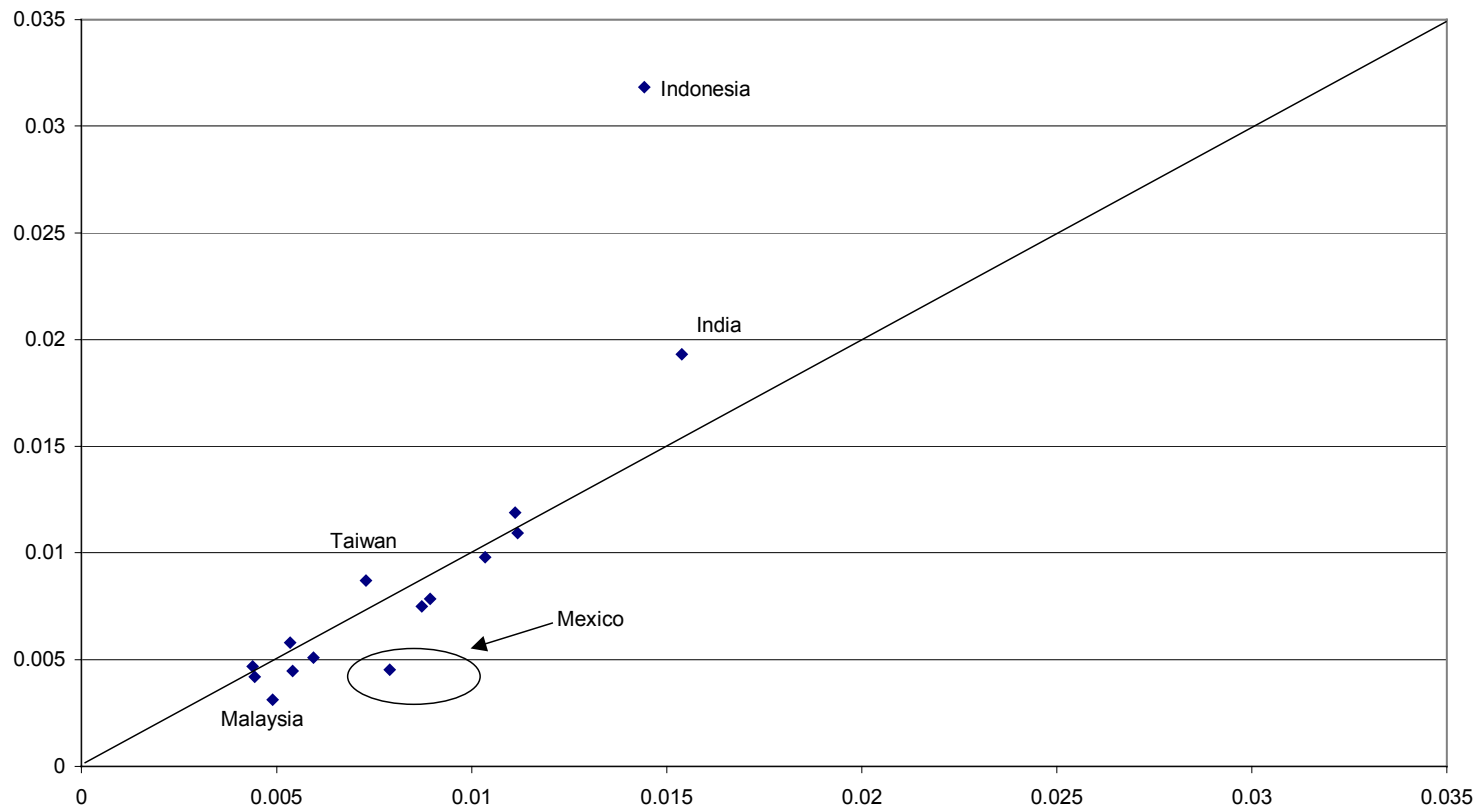

(b) Mexican-crisis period (1994.XII-1997.VI) vs Brasilian-Crisis period (1999.I-2001.VI)

Within Countries: 9194 vs 9901

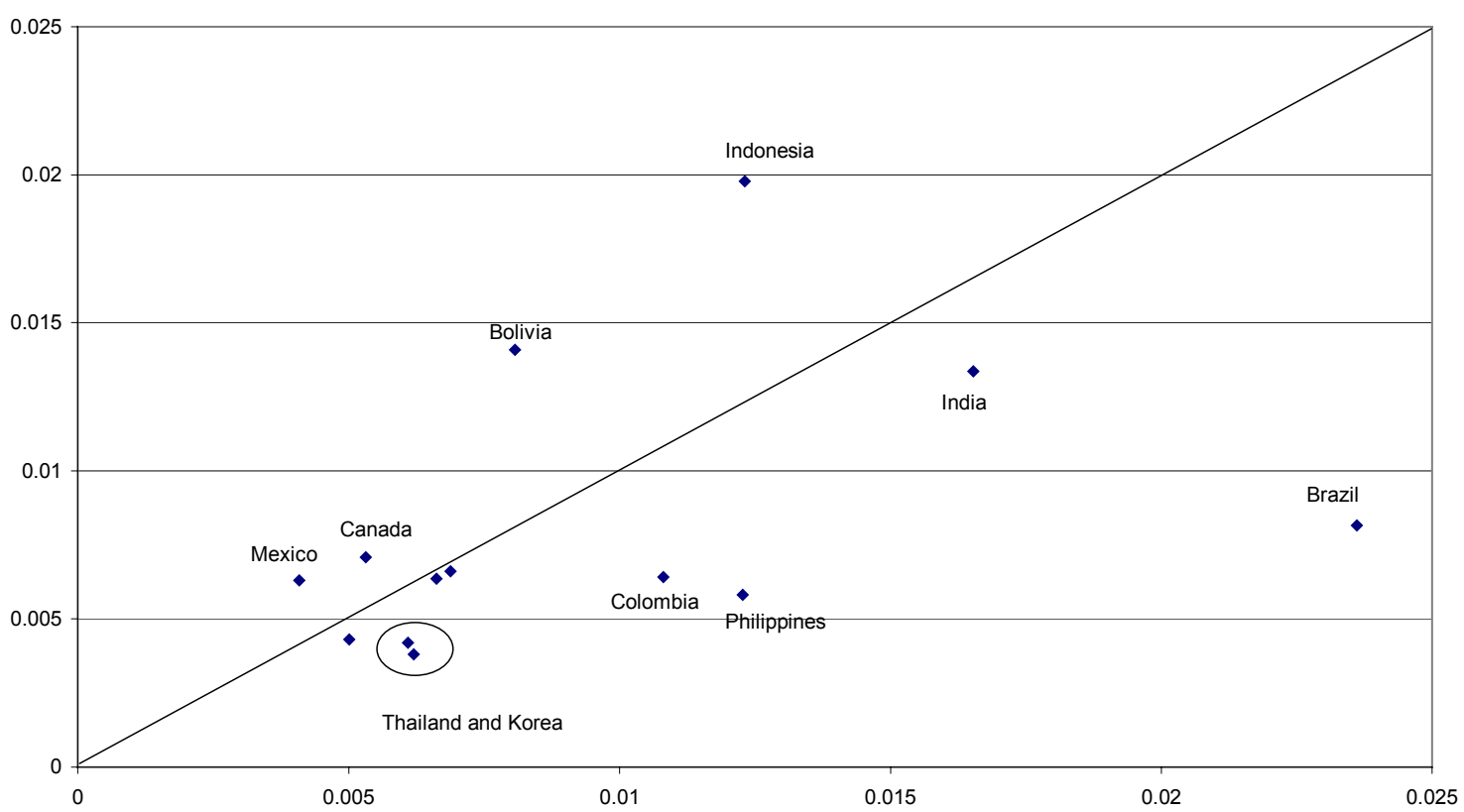

Source: own calculations 


\section{Appendix Table 1: Countries and Regions}

\begin{tabular}{|c|c|c|c|c|c|c|c|c|c|c|c|c|c|c|c|c|c|c|c|c|c|}
\hline \multirow{2}{*}{$\begin{array}{l}\text { Continen } \\
t \\
\text { Countries }\end{array}$} & \multicolumn{3}{|c|}{ North America } & \multicolumn{4}{|c|}{ Europe } & \multicolumn{4}{|c|}{ South America } & \multicolumn{8}{|c|}{ Asia } & \multicolumn{2}{|c|}{ Pacific } \\
\hline & Canada & Mexico & USA & Germany & Italy & Spain & Portugal & Argentina & Bolivia & Brazil & Colombia & India & Indonesia & Japan & Korea & Malaysia & $\begin{array}{l}\text { Philippine } \\
\text { s }\end{array}$ & Taiwan & Thailand & Australia & $\begin{array}{l}\text { NewZeala } \\
\text { nd }\end{array}$ \\
\hline \multirow[t]{13}{*}{$\begin{array}{ll}\text { Regions } \\
\end{array}$} & $\begin{array}{l}\text { Charlottetown } \\
\text { (Prinee } \\
\text { Edwards } \\
\text { Islands) }\end{array}$ & Acapulco & 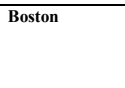 & $\begin{array}{l}\begin{array}{l}\text { Berlin } \\
\text { (Berlin) }\end{array} \\
\end{array}$ & Ancona & $\begin{array}{l}\text { Badajoz } \\
\end{array}$ & $\begin{array}{l}\text { Coimbra } \\
\text { (Centro) }\end{array}$ & $\begin{array}{l}\text { Buenos Aires } \\
\text { (Buenos Aires) }\end{array}$ & Cochabamba & Belém & $\begin{array}{l}\text { Barranquila } \\
\end{array}$ & Bangalore & Ambon & Akita & $\begin{array}{l}\text { Busan } \\
\end{array}$ & $\begin{array}{l}\text { Kota Kinabalu } \\
\text { (Sabah) }\end{array}$ & 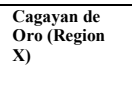 & $\begin{array}{l}\text { Chiayi } \\
\end{array}$ & $\begin{array}{l}\begin{array}{l}\text { Bangkok } \\
\text { (Bangkok } \\
\text { Metropolis) }\end{array} \\
\end{array}$ & $\begin{array}{l}\text { Adelaide } \\
\end{array}$ & Auckland \\
\hline & $\begin{array}{l}\text { Islands) } \\
\text { Edmonton } \\
\text { (Alberta) }\end{array}$ & Aguascalientes & Chicago & $\begin{array}{l}\text { Dresden } \\
\text { (Sachsen) }\end{array}$ & Bari & Barcelona & $\begin{array}{l}\text { Evora } \\
\text { (Alentejo) }\end{array}$ & $\begin{array}{l}\text { Cordoba } \\
\text { (Cordoba) }\end{array}$ & El Alto & Belo Horizonte & Bogota & Bhopal & Banda Aceh & Fukuoka & Daegu & \multirow{12}{*}{$\begin{array}{l}\text { Kuala Lumpur } \\
\text { (Peninsula } \\
\text { Malaysia) } \\
\text { Kuching } \\
\text { (Sarawak) }\end{array}$} & $\begin{array}{l}\text { Cebu(Region } \\
\text { VII) }\end{array}$ & Hsinchu & $\begin{array}{l}\text { Chiang Mai } \\
\text { (North Region) }\end{array}$ & Brisbane & Christchurch \\
\hline & $\begin{array}{l}\text { Fredericton } \\
\text { (New } \\
\text { Brumswick }\end{array}$ & Chihuahua & Cleveland & $\begin{array}{l}\text { Dissseldorf } \\
\text { (Nordrhein- } \\
\text { Westfalen }\end{array}$ & Firenze & LaCoruna & $\begin{array}{l}\begin{array}{l}\text { Faro } \\
\text { (Algarve) }\end{array}\end{array}$ & $\begin{array}{l}\begin{array}{l}\text { Formosa } \\
\text { (Formosa) }\end{array}\end{array}$ & La Paz & Brasilia & Bucaramanga & $\begin{array}{l}\text { Chennai } \\
\text { (Madras) }\end{array}$ & Bandung & Hiroshima & Daejeon & & $\begin{array}{l}\text { Cotabato(Regi } \\
\text { on XII) }\end{array}$ & Hwalien & $\begin{array}{l}\text { Hat Yai } \\
\text { (South Region) }\end{array}$ & Canberra & Dunedin \\
\hline & $\begin{array}{l}\text { Briussick) } \\
\text { Halifax } \\
\text { (Nova Scotia) }\end{array}$ & Colima & Detroit & $\begin{array}{l}\text { Weststalen) } \\
\text { Erfurt } \\
\text { (Thueringen) }\end{array}$ & Milano & Madrid & $\begin{array}{l}\text { Funchal } \\
\text { (Madeira) }\end{array}$ & $\begin{array}{l}\text { Gran Mendoza } \\
\text { (Mendoza) }\end{array}$ & Santa Cruz & Curitiba & Cali & Delhi & Bengkulu & Kagoshima & Gangneung & & $\begin{array}{l}\text { Davao(Region } \\
\text { XI) }\end{array}$ & Kaohsiu & \multirow{10}{*}{$\begin{array}{l}\text { Khon Kaen } \\
\text { (NorthlEast } \\
\text { Region) } \\
\text { Nakho } \\
\text { Ratchasima } \\
\text { (Centralalast } \\
\text { Region) }\end{array}$} & Darwin & Hamilton \\
\hline & $\begin{array}{l}\text { Quebec } \\
\text { (Quebec) }\end{array}$ & Culiacan & Houston & $\begin{array}{l}\text { Hannover } \\
\text { (Niedersachse } \\
\text { n) }\end{array}$ & Napoli & Murcia & $\begin{array}{l}\text { Lisbon } \\
\text { (LVT) }\end{array}$ & $\begin{array}{l}\text { Posadas } \\
\text { (Misiones) }\end{array}$ & & Fortaleza & Cartagena & Hyderabad & Denpasar & Kanazawa & Gwangju & & $\begin{array}{l}\text { Iloilo(Region } \\
\text { VI) }\end{array}$ & Taichung & & Hobart & Invercargill \\
\hline & $\begin{array}{l}\text { Regina } \\
\text { (Saskatchewan }\end{array}$ & Guadalajara & Los Angeles & $\begin{array}{l}\text { München } \\
\text { (Bayern) }\end{array}$ & Palermo & Oviedo & $\begin{array}{l}\text { Ponta Delgada } \\
\text { (Acores) }\end{array}$ & $\begin{array}{l}\text { Resistencia } \\
\text { (Chaco) }\end{array}$ & & Goiânia & Cucuta & Jabalpur & Jakarta & Kobe & Incheon & & $\begin{array}{l}\text { Legaspi(Regio } \\
\text { n V) }\end{array}$ & Tainan & & Melbourne & $\begin{array}{l}\text { Napier- } \\
\text { Hastings }\end{array}$ \\
\hline & $\begin{array}{l}\text { Sain John's } \\
\text { (New } \\
\text { Foundland) }\end{array}$ & Hermosillo & New York & $\begin{array}{l}\text { Saarbrïkken } \\
\text { (Saarland) }\end{array}$ & $\begin{array}{l}\text { Reggio } \\
\text { Calabria }\end{array}$ & Pamplona & $\begin{array}{l}\text { Porto } \\
\text { (Norte) }\end{array}$ & $\begin{array}{l}\text { Salta } \\
\text { (Salta) }\end{array}$ & & Porto Alegre & Manizales & Jaipur & Kupang & Kyoto & Mokpo & & $\begin{array}{l}\text { Manila(Nat. } \\
\text { Capital } \\
\text { Repion) }\end{array}$ & Taipei & & Perth & New Plymouth \\
\hline & $\begin{array}{l}\text { Toronto } \\
\text { (Ontario) }\end{array}$ & $\begin{array}{l}\text { Ciuadad } \\
\text { Juarez }\end{array}$ & Philadelphia & $\begin{array}{l}\text { Schwerin } \\
\text { (Mecklenburg- } \\
\text { Vorpommern) }\end{array}$ & Roma & Saragossa & & $\begin{array}{l}\text { San Salvador } \\
\text { de Jujuy } \\
\text { (Jujuy) }\end{array}$ & & Recife & Medellin & Kolkata & Manado & Nagoya & Seoul & & $\begin{array}{l}\text { Tacloban(Regi } \\
\text { on VIII) }\end{array}$ & & & Sydney & Timaru \\
\hline & $\begin{array}{l}\text { Victoria } \\
\text { (British } \\
\text { Colombia) }\end{array}$ & Merida & San Francisco & $\begin{array}{l}\text { Stutgart } \\
\text { (Baden- } \\
\text { Wuerttemberg }\end{array}$ & Torino & Seville & & $\begin{array}{l}\text { Tucuman } \\
\text { (Tucuman) }\end{array}$ & & Rio de Janeiro & Monteria & Lucknow & Medan & Niigata & Suwon & & $\begin{array}{l}\text { Tuguegaraa(R } \\
\text { egion II) }\end{array}$ & & & & Wanganui \\
\hline & \multirow[t]{4}{*}{$\begin{array}{l}\text { Winnipeg } \\
\text { (Manitoba) }\end{array}$} & Mexicali & & $\begin{array}{l}\text { Wiesbaden } \\
\text { (Hessen) }\end{array}$ & Venezia & Valencia & & $\begin{array}{l}\text { Ushuaia } \\
\text { (Tierra del } \\
\text { Fuego) }\end{array}$ & & Salvador & Neiva & Madurai & Pakanbaru & Sapporo & Wonju & & $\begin{array}{l}\text { Zamboanga(R } \\
\text { egion IX) }\end{array}$ & & & & Wellington \\
\hline & & Mexico & & & & & & & & São Paulo & Pasto & $\underset{\substack{\text { Mumbai } \\
\text { (Bombar) }}}{ }$ & Palembang & Sendai & & & & & & & \\
\hline & & $\begin{array}{l}\text { Monterrey } \\
\text { Puubla } \\
\text { San Luis } \\
\text { Potosi }\end{array}$ & & & & & & & & & $\begin{array}{l}\text { Pereira } \\
\text { Villavicencio }\end{array}$ & $\begin{array}{l}\text { Nagpur } \\
\text { Patna } \\
\text { Surat }\end{array}$ & $\begin{array}{l}\text { Pontianak } \\
\text { Samarinda } \\
\text { Surabaya }\end{array}$ & Tokyo & & & & & & & \\
\hline & & Villahermosa & & & & & & & & & & $\begin{array}{l}\text { Vishakhapatn } \\
\text { am }\end{array}$ & $\begin{array}{l}\text { Ujung } \\
\text { Pandang }\end{array}$ & & & & & & & & \\
\hline \# regions & 10 & 15 & 9 & 10 & 10 & 10 & 7 & 10 & 4 & 11 & 13 & 15 & 15 & 12 & 10 & 3 & 10 & 7 & 5 & 8 & 10 \\
\hline Frequency & monthly & monthly & monthly/bi- & monthly & monthly & monthly & monthly & monthly & monthly & monthly & monthly & monthly & monthly & monthly & monthly & monthly & monthly & monthly & monthly & quarterly & quarterly \\
\hline $\begin{array}{l}\text { Sample } \\
\text { Period: }\end{array}$ & $\begin{array}{l}1991.01- \\
2001.06\end{array}$ & $\begin{array}{l}\text { 1991.01 - } \\
2001.06\end{array}$ & $\begin{array}{l}19101.01- \\
2001.06\end{array}$ & $\begin{array}{l}1991.01- \\
2001.06\end{array}$ & $\begin{array}{l}1991.01- \\
2001.06\end{array}$ & $\begin{array}{l}1991.01- \\
2001.06\end{array}$ & $\begin{array}{l}1991.01- \\
2001.06\end{array}$ & $\begin{array}{l}\text { 1991.01- } \\
1998.12\end{array}$ & $\begin{array}{l}1992.01- \\
2001.06\end{array}$ & $\begin{array}{l}\text { 1991.01- } \\
2001.06\end{array}$ & $\begin{array}{l}1991.01- \\
2001.06\end{array}$ & $\begin{array}{l}1991.01- \\
2000.12\end{array}$ & $\begin{array}{l}1991.01- \\
2001.06\end{array}$ & $\begin{array}{l}1999.01- \\
2001.04\end{array}$ & $\begin{array}{l}1991.01- \\
2000.12\end{array}$ & $\begin{array}{l}1994.01- \\
2001.05\end{array}$ & $\begin{array}{l}\text { 1991.01- } \\
2001.08\end{array}$ & $\begin{array}{l}\text { 1996.01- } \\
2001.01\end{array}$ & $\begin{array}{l}\text { 1991.01- } \\
2001.06\end{array}$ & $\begin{array}{l}1991.03- \\
2001.06\end{array}$ & $\begin{array}{l}1993.12- \\
2000.09\end{array}$ \\
\hline Exceptions: & & & $\begin{array}{l}\text { bimonthly, } \\
\text { odd: bost, clev } \\
\text { bimonthly, } \\
\text { even: hous, } \\
\text { detr, phil, sanf }\end{array}$ & & & & & & $\begin{array}{l}1992.11 \text { and } \\
1992.12 \text { are } \\
\text { missing (m.v. } \\
\text { are in raw files } \\
\text { instead) }\end{array}$ & $\begin{array}{l}1991.08 \text { is } \\
\text { missing (m.v. } \\
\text { are in raw files } \\
\text { instead) }\end{array}$ & & & & & & & & & & & $\begin{array}{l}\text { auck, chris } \\
\text { and wll start in } \\
1991.03\end{array}$ \\
\hline Source: & $\begin{array}{l}\text { Statisitic } \\
\text { CCanda } \\
\text { (CANSIM) }\end{array}$ & $\begin{array}{l}\text { Banco de } \\
\text { México }\end{array}$ & $\begin{array}{l}\text { Bureau of } \\
\text { LLabor } \\
\text { Statistics }\end{array}$ & $\begin{array}{l}\text { Various } \\
\text { Statistical } \\
\text { Offices of the } \\
\text { "Laender" } \\
\text { (Provinces) in } \\
\text { Germany }\end{array}$ & $\begin{array}{l}\text { Istituto } \\
\text { Nazionale di } \\
\text { Statistica } \\
\text { (ISTAT) }\end{array}$ & $\begin{array}{l}\text { Instituto } \\
\text { Nacional de } \\
\text { Estaidistica } \\
\text { (INE) }\end{array}$ & $\begin{array}{l}\text { Instituto } \\
\text { Nacional de } \\
\text { Estatistica } \\
\text { (INE) }\end{array}$ & $\begin{array}{l}\text { Instituto } \\
\text { Nacional de } \\
\text { Estaditica y } \\
\text { Censos } \\
\text { (INDEC) }\end{array}$ & $\begin{array}{l}\text { Instituto } \\
\text { Nacional de } \\
\text { Estadistica } \\
\text { (INE) }\end{array}$ & $\begin{array}{l}\text { Instituto } \\
\text { Brasileiro de } \\
\text { Geografia e } \\
\text { Estatistica } \\
\text { (IBGE) }\end{array}$ & $\begin{array}{l}\text { Departamento } \\
\text { Administrativiv } \\
\text { o Nacional de } \\
\text { Estadistica } \\
\text { (DANE) }\end{array}$ & $\begin{array}{l}\text { Government of } \\
\text { India, } \\
\text { Ministry of } \\
\text { Statistits and } \\
\text { Programme } \\
\text { Implementatio } \\
\text { n }\end{array}$ & $\begin{array}{l}\text { Badan Pusat } \\
\text { Statistiki } \\
\text { (Statistics, } \\
\text { Indonesia, } \\
\text { BPS) }\end{array}$ & $\begin{array}{l}\text { Statistics } \\
\text { Bureau \& } \\
\text { Statistics } \\
\text { Center, } \\
\text { Ministry of } \\
\text { Public } \\
\text { Management, } \\
\text { Home Affairs, } \\
\text { Posts and } \\
\text { Telecommunic } \\
\text { ations }\end{array}$ & $\begin{array}{l}\text { National } \\
\text { Statistical } \\
\text { Office (NSO) }\end{array}$ & $\begin{array}{l}\text { JABATAN } \\
\text { PERANGKAA } \\
\text { N MALAYSIA } \\
\text { (Department } \\
\text { of Statistics } \\
\text { Malaysia) }\end{array}$ & $\begin{array}{l}\text { National } \\
\text { Statistical } \\
\text { Office (NSO) }\end{array}$ & $\begin{array}{l}\text { Directorate- } \\
\text { General of } \\
\text { Budgte, } \\
\text { Accounting } \\
\text { and Statistics }\end{array}$ & $\begin{array}{l}\text { Department of } \\
\text { Internal } \\
\text { Trade, } \\
\text { Ministry of } \\
\text { Commerce }\end{array}$ & $\begin{array}{l}\text { Australian } \\
\text { Bureau of } \\
\text { Statistists } \\
\text { (ABS) }\end{array}$ & $\begin{array}{l}\text { Statistics New } \\
\text { Zealand (SNZ) }\end{array}$ \\
\hline
\end{tabular}




\section{Appendix Table 2a: CPI, All Items}

Estimation Using Quadratic Distance Function, Overall Period (Jan 1991 - June 2001), Volatility Measure 1

(Grouped by Continents)

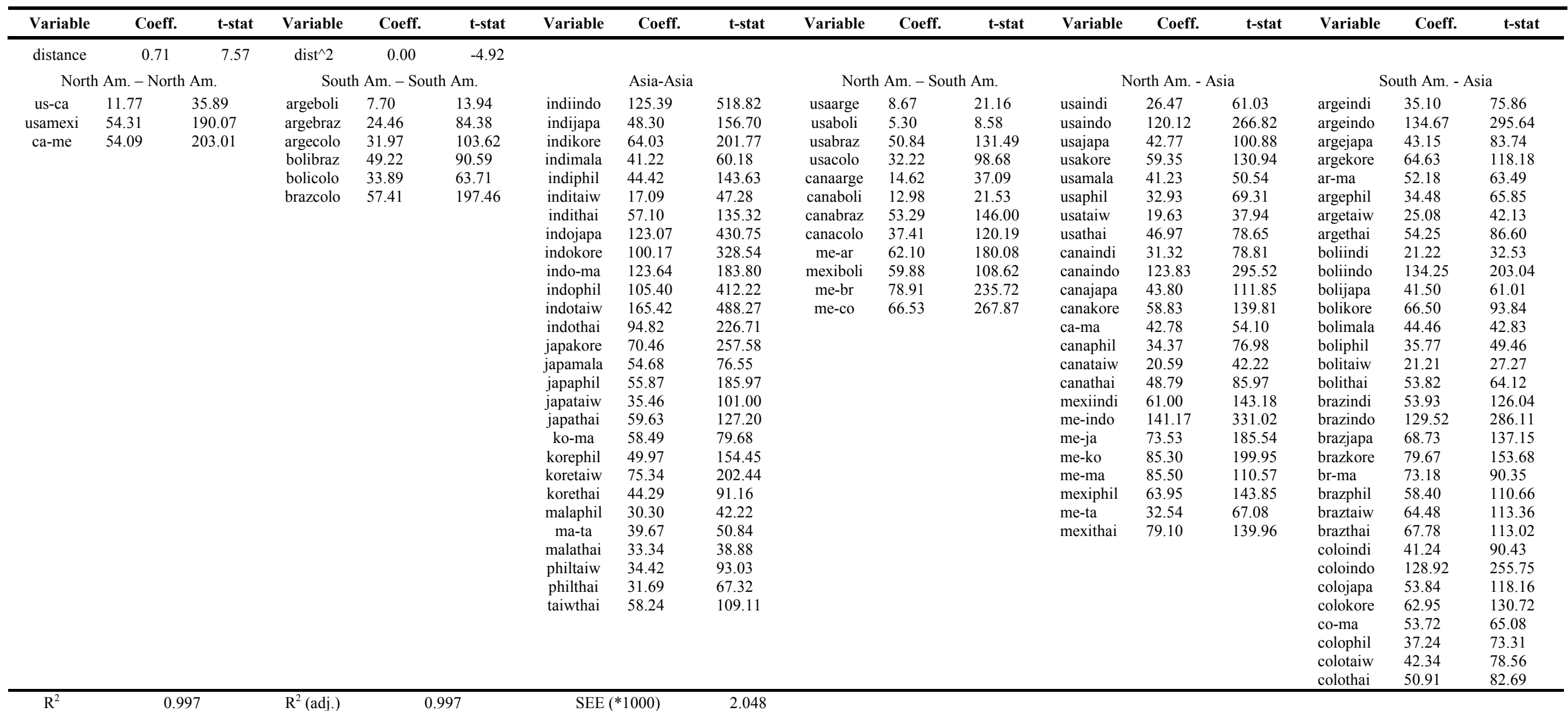

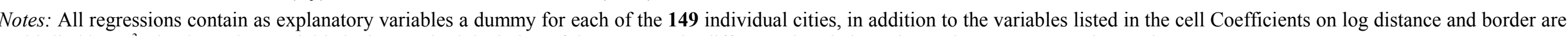
multiplied by $10^{3}$ The dependent variable is the standard deviation of the two-months difference in relative prices. There are 11026 observations. 
Appendix Table 2b: CPI, All Items

Estimation Using Log Distance Function, Overall Period (Jan 1991 - June 2001), Volatility Measure 2

Grouped by Continents

\begin{tabular}{|c|c|c|c|c|c|c|c|c|c|c|c|c|c|c|c|c|c|}
\hline Variable & Coeff. & t-stat & Variable & Coeff. & t-stat & Variable & Coeff. & t-stat & Variable & Coeff. & t-stat & Variable & Coeff. & t-stat & Variable & Coeff. & t-stat \\
\hline $\ln ($ distance $)$ & 0.78 & 14.12 & & & & & & & & & & & & & & & \\
\hline \multicolumn{3}{|c|}{ North Am. - North Am. } & \multicolumn{3}{|c|}{ South Am. - South Am. } & \multicolumn{3}{|c|}{ Asia-Asia } & \multicolumn{3}{|c|}{ North Am. - South Am. } & \multicolumn{3}{|c|}{ North Am. - Asia } & \multicolumn{3}{|c|}{ South Am. - Asia } \\
\hline us-ca & 30.72 & 35.58 & argeboli & 23.29 & 11.57 & indiindo & 187.81 & 552.22 & usaarge & 17.99 & 23.09 & usaindi & 37.04 & 77.25 & argeindi & 50.59 & 101.73 \\
\hline usamexi & 72.66 & 188.51 & argebraz & 40.66 & 82.76 & indijapa & 94.34 & 167.70 & usaboli & 18.79 & 6.87 & usaindo & 141.38 & 353.10 & argeindo & 97.91 & 405.39 \\
\hline \multirow[t]{27}{*}{ ca-me } & 79.06 & 204.64 & argecolo & 67.92 & 100.11 & indikore & 83.68 & 194.28 & usabraz & 66.19 & 147.23 & usajapa & 103.62 & 116.62 & argejapa & 97.17 & 110.81 \\
\hline & & & bolibraz & 55.63 & 86.90 & indimala & 67.95 & 60.01 & usacolo & 69.36 & 96.32 & usakore & 40.89 & 142.73 & argekore & 65.55 & 146.14 \\
\hline & & & bolicolo & 73.48 & 58.22 & indiphil & 92.62 & 146.34 & canaarge & 41.34 & 42.53 & usamala & 59.18 & 54.45 & ar-ma & 92.79 & 69.41 \\
\hline & & & brazcolo & 94.20 & 196.07 & inditaiw & 41.16 & 41.32 & canaboli & 39.78 & 20.30 & usaphil & 73.50 & 82.14 & argephil & 73.61 & 84.01 \\
\hline & & & & & & indithai & 74.45 & 132.78 & canabraz & 79.24 & 168.20 & usataiw & 45.32 & 39.42 & argetaiw & 62.40 & 48.25 \\
\hline & & & & & & indokore & 107.08 & 318.64 & me-ar & 96.97 & 205.04 & canaindi & 53.56 & 101.31 & boliindi & 39.15 & 34.39 \\
\hline & & & & & & indo-ma & 167.30 & 184.80 & mexiboli & 85.50 & 106.83 & canaindo & 139.61 & 400.91 & boliindo & 159.60 & 228.68 \\
\hline & & & & & & indophil & 108.13 & 401.63 & me-br & 123.14 & 278.66 & canajapa & 103.53 & 130.55 & bolijapa & 107.86 & 64.73 \\
\hline & & & & & & indotaiw & 304.73 & 458.80 & me-co & 99.38 & 257.27 & canakore & 59.79 & 152.52 & bolikore & 50.89 & 97.17 \\
\hline & & & & & & indothai & 103.25 & 225.16 & & & & ca-ma & 62.33 & 58.25 & bolimala & 62.49 & 44.33 \\
\hline & & & & & & japakore & 113.15 & 244.67 & & & & canaphil & 81.93 & 92.59 & boliphil & 75.71 & 52.99 \\
\hline & & & & & & japamala & 122.96 & 76.36 & & & & canataiw & 52.51 & 44.05 & bolitaiw & 43.83 & 26.24 \\
\hline & & & & & & japaphil & 144.80 & 175.54 & & & & canathai & 68.45 & 96.35 & bolithai & 59.41 & 67.85 \\
\hline & & & & & & japataiw & 82.52 & 89.39 & & & & mexiindi & 84.57 & 201.43 & brazindi & 84.70 & 170.76 \\
\hline & & & & & & japathai & 107.81 & 125.35 & & & & me-indo & 224.05 & 482.34 & brazindo & 193.20 & 413.43 \\
\hline & & & & & & ko-ma & 107.09 & 77.79 & & & & me-ja & 154.29 & 230.51 & brazjapa & 149.19 & 188.14 \\
\hline & & & & & & korethai & 63.84 & 85.32 & & & & mexiphil & 101.73 & 181.25 & brazphil & 102.00 & 150.22 \\
\hline & & & & & & malaphil & 72.63 & 41.49 & & & & me-ta & 81.44 & 73.14 & braztaiw & 103.64 & 135.16 \\
\hline & & & & & & ma-ta & 62.61 & 48.69 & & & & mexithai & 126.16 & 163.78 & brazthai & 112.93 & 132.91 \\
\hline & & & & & & malathai & 63.58 & 38.46 & & & & & & & coloindi & 83.07 & 118.54 \\
\hline & & & & & & philtaiw & 77.84 & 84.16 & & & & & & & coloindo & 139.96 & 375.57 \\
\hline & & & & & & philthai & 72.23 & 64.19 & & & & & & & colojapa & 114.16 & 143.32 \\
\hline & & & & & & taiwthai & 110.24 & 102.68 & & & & & & & colokore & 104.99 & 146.32 \\
\hline & & & & & & & & & & & & & & & co-ma & 103.56 & 72.13 \\
\hline & & & & & & & & & & & & & & & colophil & 90.22 & 90.58 \\
\hline & & & & & & & & & & & & & & & colotaiw & 123.62 & 85.08 \\
\hline & & & & & & & & & & & & & & & colothai & 81.81 & $\begin{array}{l}0.000 \\
96.25\end{array}$ \\
\hline
\end{tabular}

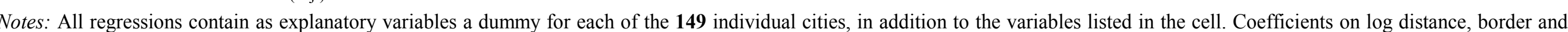
SSE are multiplied by $10^{3}$. The dependent variable is spread between the $10^{\text {th }}$ and $90^{\text {th }}$ percentile of the two-months difference in relative prices. There are 11026 observations. 


\section{CFS Working Paper Series:}

\begin{tabular}{lll} 
No. & Author(s) & Title \\
\hline $2001 / 02$ & Roland Beck & $\begin{array}{l}\text { Do Country Fundamentals Explain Emerging } \\
\text { Market Bond Spreads? }\end{array}$ \\
$2001 / 03$ & $\begin{array}{l}\text { Markus Kern } \\
\text { Bernd Rudolph }\end{array}$ & $\begin{array}{l}\text { Comparative Analysis of Alternative Credit } \\
\text { Risk Models - An Application on German } \\
\text { Middle Market Loan Portfolios - }\end{array}$ \\
$2001 / 04$ & $\begin{array}{l}\text { Antje Brunner } \\
\text { Jan Pieter Krahnen }\end{array}$ & $\begin{array}{l}\text { Multiple Lenders and Corporate Distress: } \\
\text { Evidence on Debt Restructuring }\end{array}$ \\
$2001 / 05$ & $\begin{array}{l}\text { Ralf Ewert } \\
\text { Andrea Szczesny }\end{array}$ & $\begin{array}{l}\text { Countdown for the New Basle Capital Accord. } \\
\text { Are German Banks Ready for the Internal } \\
\text { Ratings-Based Approach? }\end{array}$ \\
$2001 / 06$ & Bernd Kaltenhäuser & $\begin{array}{l}\text { Explaining the Dollar-Euro Rate: Do Stock } \\
\text { Market Returns Matter? }\end{array}$ \\
$2001 / 07$ & $\begin{array}{l}\text { Guenter Beck } \\
\text { Axel A. Weber }\end{array}$ & $\begin{array}{l}\text { How wide are European borders? New Evidence } \\
\text { on the Integration Effects of Monetary Unions }\end{array}$ \\
$2001 / 08$ & $\begin{array}{l}\text { Yunus Aksoy } \\
\text { Tomasz Piskorski }\end{array}$ & Domestic Money and US Output and Inflation \\
\end{tabular}

2001/09 Elke Hahn

Core Inflation in the Euro Area: Evidence from the Structural VAR Approach

2001/10 Olaf Ehrhardt

Eric Nowak

2001/11 Daniel Gross

2001/12 Daniel Gross

2001/13 Guenter Beck

Axel A. Weber
Private Benefits and Minority Shareholder Expropriation - Empirical Evidence from IPOs of German Family-Owned Firms

Country-Specific and Global Shocks in the Business Cycle

Trade Flows and the International Business Cycle

Economic Integration and the Exchange Rate Regime: How Damaging are Currency Crises?

Copies of working papers are available at the Center for Financial Studies or can be downloaded (http://www.ifk-cfs.de). 